\title{
Bioavailability of organically bound Fe to model phytoplankton of the Southern Ocean
}

\author{
C. S. Hassler ${ }^{1, *}$ and V. Schoemann ${ }^{2}$ \\ ${ }^{1}$ Centre for Australian Weather and Climate Research (CAWCR), a partnership between CSIRO and the Bureau of \\ Meteorology, Castray Esplanade, Hobart, 7000, TAS, Australia \\ ${ }^{2}$ Ecologie des Systèmes Aquatiques, Université Libre de Bruxelles, Campus de la Plaine, CP 221, Boulevard du Triomphe, \\ 1050 Bruxelles, Belgium \\ *now at: Plant Functional Biology and Climate Change Cluster, University of Technology, Sydney, P.O. Box 123 Broadway, \\ 2007, NSW, Australia
}

Received: 14 November 2008 - Published in Biogeosciences Discuss.: 4 February 2009

Revised: 2 September 2009 - Accepted: 17 September 2009 - Published: 30 October 2009

\begin{abstract}
Iron (Fe) is known to be mostly bound to organic ligands and to limit primary productivity in the Southern Ocean. It is thus important to investigate the bioavailability of organically bound Fe. In this study, we used four phytoplankton species of the Southern Ocean (Phaeocystis sp., Chaetoceros sp., Fragilariopsis kerguelensis and Thalassiosira antarctica Comber) to measure the influence of various organic ligands on Fe solubility and bioavailability. Short-term uptake $\mathrm{Fe}: \mathrm{C}$ ratios were inversely related to the surface area to volume ratios of the phytoplankton. The ratio of extracellular to intracellular $\mathrm{Fe}$ is used to discuss the relative importance of diffusive supply and uptake to control Fe bioavailability. The effect of excess organic ligands on Fe bioavailability cannot be solely explained by their effect on Fe solubility. For most strains studied, the bioavailability of $\mathrm{Fe}$ can be enhanced relative to inorganic $\mathrm{Fe}$ in the presence of porphyrin, catecholate siderophore and saccharides whereas it was decreased in presence of hydroxamate siderophore and organic amine. For Thalassiosira, iron bioavailability was not affected by the presence of porphyrin, catecholate siderophore and saccharides. The enhancement of Fe bioavailability in presence of saccharides is presented as the result from both the formation of bioavailable (or chemically labile) organic form of $\mathrm{Fe}$ and the stabilisation of Fe within the dissolved phase. Given the ubiquitous presence of saccharides in the ocean, these compounds might represent an important factor to control the basal level of soluble
\end{abstract}

Correspondence to: C. S. Hassler (christel.hassler@uts.edu.au) and bioavailable Fe. Results show that the use of model phytoplankton is promising to improve mechanistic understanding of Fe bioavailability and primary productivity in HNLC regions of the ocean.

\section{Introduction}

The regulating role of the ocean on the Earth's climate system has been widely recognised. During the last 15 years, microcosm experiments (e.g. de Baar et al., 1990) and large scale natural or in-situ $\mathrm{Fe}$ fertilisation experiments (e.g. de Baar et al., 2005) have demonstrated that Fe controls primary productivity, as well as the planktonic community structure in more than $30 \%$ of the oceans (High-Nutrient, Low-Chlorophyll areas - HNLC). In HNLC regions of the ocean, the concentration of total dissolved $\mathrm{Fe}$ is low (e.g. 0.1-0.6 nmol L ${ }^{-1}$ in the Southern Ocean, SO, de Baar and de Jong, 2001). Fe is usually present in different physical (particulate, colloidal, soluble) and chemical (inorganic and organic complexes) forms. A fraction (viz. the bioavailable fraction) of this $\mathrm{Fe}$ is expected to be accessible for phytoplankton growth, therefore controlling the plankton abundance and diversity (e.g. de Baar et al., 2005). Fe bioavailability is influenced by its chemical forms, biogeochemical cycling and the different uptake strategies of the phytoand bacterio-plankton communities (Barbeau et al., 1996; Hutchins et al., 1999; Nodwell and Price, 2001; Strzepek et al., 2005; Maldonado et al., 2005). Because of highly dynamic and complex biogeochemical processes, Fe bioavailability is currently difficult to predict. 
The members of the planktonic community are thought to be in competition for available Fe (Worms et al., 2006), when in short supply, possibly to the extent of sequestering it from others with their own ligands (e.g. Völker and Wolf-Gladrow, 1999). For example, large diatoms, have a lesser diffusive supply (Pahlow et al., 1997) of Fe and a possibly less efficient uptake strategy (e.g. surface reductase, FeEDTA reported as non-bioavailable, Shaked et al., 2005) than small cyanobacteria (e.g. siderophore excretion/recognition, Fe-EDTA reported as bioavailable, Hassler and Twiss, 2006). Distinguishing amongst different $\mathrm{Fe}$ uptake strategies is often not that simple. In fact, some eukaryotic phytoplankton can excrete organic compounds that could interact with $\mathrm{Fe}$ chemistry or the microorganisms present (Boyé and van den Berg, 2000; Zhang and Wang, 2004; Rijkenberg et al., 2008). Regeneration of $\mathrm{Fe}$, through grazing, bacterial and viral activities, is another pathway that supplies the micronutrient to phytoplanktonic communities (Barbeau et al., 1996; Poorvin et al., 2004; Strzepek et al., 2005).

It has been shown that dissolved inorganic $\mathrm{Fe}$ concentrations are often insufficient to sustain the growth of planktonic organisms as observed in HNLC regions of the ocean (Price and Morel, 1998). Titration using the competitive ligand exchange adsorptive stripping voltammetry (CLEAd$\mathrm{CSV}$ ) revealed that most of the Fe (94-99.9\%, e.g. Boyé et al., 2001) is associated with organic ligands. Even if some of these organic ligands have similar binding affinities for Fe as siderophore and porphyrin (Rue and Bruland, 1995; Witter et al., 2000), they still remain poorly characterised. The detection of weak and strong organic ligands is somewhat limited in the CLEAdCSV technique because of defined analytical windows (depending on the competitive ligand added,

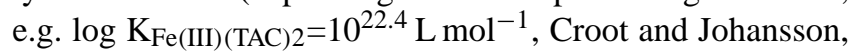
2000 ) in which organic ligands bound to Fe can be detected. Most of the organic compounds in the open ocean would be biologically produced in situ. For example, siderophores are mainly bacterially produced (e.g. Völker and Wolf-Gladrow, 1999), carbohydrates such as exopolymeric substances are excreted by both prokaryotic and eukaryotic plankton (e.g. Hoagland et al., 1993; Mancuso et al., 2005), porphyrins are released upon grazing and cell lysis of plankton (Hutchins et al., 1999; Gledhill, 2007; Vong et al., 2007), some organic ligands could also be released because of viral activity (Poorvin et al., 2004). Whereas siderophores and porphyrins are known to directly affect $\mathrm{Fe}$ chemistry and bioavailability (e.g. Rue and Bruland, 1995; Hutchins et al., 1999), little is known about the possible role of carbohydrates in the $\mathrm{Fe}$ oceanic cycle. A significant fraction (3-30\%) of the dissolved organic carbon is present as carbohydrates (Wang et al., 2006). Acylated and acid saccharides are a significant reactive group (Wang et al., 2006; Panagiotopoulos et al., 2007) that has been shown to be important for carbon (Engel et al., 2004) and trace elements (Santschi et al., 2003) cycles. Saccharides could affect $\mathrm{Fe}$ cycling by chemical interactions (complexation, photo-degradation and/or effect on $\mathrm{Fe}$ solubility) or by biological processes. They can be a storage product for phytoplankton and a substrate for heterotrophic plankton; both known to be Fe responsive (e.g. Kirchman et al., 2000; van Oijen et al., 2005). Because organic ligands are biologically produced and most of the $\mathrm{Fe}$ is bound to organic ligands, the organically bound Fe might well be a significant fraction controlling Fe bioavailability. In addition, organic complexation prevents or slows down precipitation, coagulation and settling in seawater (Chen et al., 2004; Tian et al., 2006).

To date, several studies have demonstrated the importance of organic ligands to control $\mathrm{Fe}$ bioavailability to natural phytoplankton communities from the SO (e.g. Hutchins et al., 1999; Maldonado et al., 2005; Schoemann et al., 2009). Whereas, work with natural phytoplankton is environmentally relevant, it provides little information on the processes controlling the bioavailability of organically bound Fe. In this study, the bioavailability of relevant forms of organically bound $\mathrm{Fe}$ was addressed at the species level using polar phytoplankton species. Four strains were selected to represent various groups (diatoms and haptophytes) with likely differing Fe uptake strategies. Since size affects Fe diffusive supply and biological requirement (Sunda and Huntsman, 1995) and because the natural phytoplanktonic assemblage is variable in size, shape and morphological form, single cell, colonial or chain forming phytoplankton were chosen. For each strain, $\mathrm{Fe}$ bioavailability and carbon fixation were measured using short-term ${ }^{55} \mathrm{Fe}$ and ${ }^{14} \mathrm{C}$ bioaccumulation. The bioavailability of added inorganic $\mathrm{Fe}$, as well as $\mathrm{Fe}$ bound to siderophores, porphyrin, organic amine and saccharides, was studied in natural water collected from the SO. Results are discussed in the framework of the mechanistic role that organically bound Fe plays in controlling Fe solubility, bioavailability and primary productivity. Mechanistic understanding of Fe bioavailability is required before one proceeds to interpretation of the phytoplankton dynamics in response to $\mathrm{Fe}$ in the oceans.

\section{Material and methods}

\subsection{Choice of microorganisms}

Since Fe bioavailability depends both on the size and the phytoplankton species (e.g. Sunda and Huntsman, 1995; Völker and Wolf-Gladrow, 1999; Timmermans et al., 2001, 2004), relevant phytoplankton from the SO were selected accordingly from the Australian National Algae Culture Collection. Phaeocystis is known to recurrently bloom in the SO (Schoemann et al., 2005), it was therefore chosen to be representative of the haptophyte group. Phaeocystis sp. (CS 243, isolated from Antarctica, $68^{\circ} 47.5^{\prime} \mathrm{S}, 73^{\circ} 30.2^{\prime} \mathrm{E}$ ) is mainly present as single cell $(78 \%$, determined as per Becquevort et al., 2007; $5.1 \mu \mathrm{m}$ cellular diameter, $69 \mu \mathrm{m}^{3}$ cellular biovolume as measured by microscopy, Table 1) 
and small colonies (up to $100 \mu \mathrm{m}$ diameter) in our culture medium. Although little is known on the mechanism of $\mathrm{Fe}$ transport in Phaeocystis, a complex interaction (likely involving complexation) between $\mathrm{Fe}$ and the surrounding $\mathrm{C}$ rich mucus from the colonies was recognised (Schoemann et al., 2001). Due to lower A/V ratio of the colonies, Phaeocystis cells in colonies are expected to have higher halfsaturation constants for growth than solitary cells. It was previously observed that $\mathrm{Fe}$ addition could have an effect on the morphotype dominance (colonies vs. solitary cells) of Phaeocystis antarctica with proportionnally more solitary cells under low Fe conditions (Becquevort et al., 2007). Diatoms are an important group of phytoplankton present worldwide (Sarthou et al., 2005) and were selected to represent various taxa with variable size and morphological forms. Chaetoceros sp. (CS 624, isolated from Prydz Bay, Antarctica) is a small single cell diatom (inverted microscopy: $3.9 \mu \mathrm{m}$ spherical equivalent diameter, $31 \mu \mathrm{m}^{3}$ biovolume). Thalassiosira antarctica Comber (CCMP 982) is a larger diatom (inverted microscopy: $14.9 \mu \mathrm{m}$ spherical equivalent diameter, $1747 \mu \mathrm{m}^{3}$ biovolume), isolated from Oslo Fjord $\left(59.5^{\circ} \mathrm{N}, 10.6^{\circ} \mathrm{E}\right.$, Norway). Fragilariopsis kerguelensis is a diatom (inverted microscopy: $25.0 \mu \mathrm{m}$ cellular spherical equivalent diameter, $8150 \mu \mathrm{m}^{3}$ cellular biovolume) forming long chains (average cell number per chain $28 \pm 12, n=23$ ) isolated from Antarctica (53.5 $\mathrm{S}, 141.5^{\circ} \mathrm{E}$, October 2006) by Kristen Karsh (CSIRO).

Two of the strains (Chaetoceros sp. and Phaeocystis sp.) used in this study were used to study iron bioavailability and physiological responses during acclimation from ironreplete (AQUIL) to low iron concentration (SO water with [Fe]dissolved $=0.3 \mathrm{nM}$; Hassler et al., 2009a). Consistent with the occurrence of iron limitation in SO water, growth rate, $\mathrm{Fv} / \mathrm{Fm}$ and cell size all decreased by $15-65 \%$; the growth rate and $\mathrm{Fv} / \mathrm{Fm}$ for Phaeocystis and Chaeotoceros in Southern Ocean water were 0.14 and $0.15 \mathrm{~d}^{-1}$ and 0.46 and 0.41 , respectively (Hassler et al., 2009a). In addition, Phaeocystis forming large colonies $(>300 \mu \mathrm{m})$ in AQUIL, was mainly present as solitary cells in the SO water as being observed here, a sign that Phaeocystis was indeed ironlimited (Becquevort et al., 2007). It is reasonable to assume that larger species (Thalassiosira and Fragilariopsis), more prone to iron limitation, are also iron-limited in this study.

\subsection{Growth media and culture condition}

Batch cultures were maintained in exponential growth phase in an incubation cabinet (RUMED Model 1301) at $2^{\circ} \mathrm{C}$ with a $18 \mathrm{~h}: 6 \mathrm{~h}$ light:dark cycle at photosynthetic saturating light levels. Phaeocystis was grown under $120 \mu \mathrm{mol}$ photons $\mathrm{m}^{-2} \mathrm{~s}^{-1}$ and diatoms at $60 \mu$ mol photons $\mathrm{m}^{-2} \mathrm{~s}^{-1}$. Light level was chosen to provide near optimal maximum quantum yield ( $\mathrm{Fv} / \mathrm{Fm})$ above 0.58 (Water-PAM, Heinz Walz $\mathrm{GmbH}$ ) under iron replete condition (AQUIL media, Morel et al., 1975); light was adjusted using neutral density filters. All strains were maintained at least for 1-year in open Southern Ocean filtered seawater, collected during the SAZ-SENSE oceanographic voyage using trace metal clean techniques, with dissolved Fe from 0.2 to $0.3 \mathrm{nmol} \mathrm{L}^{-1}$ (Lannuzel et al., 2009). Cultures were transferred every 15 to 20 days into filtered seawater $(0.2 \mu \mathrm{m}$, Sartorius membrane filter cartridges Sartobran) collected during the ISPOL oceanographic voyage $\left(68^{\circ} \mathrm{S}\right.$, $55^{\circ} \mathrm{W}$, Lannuzel et al., 2008) for at least six weeks prior to experimentation. In this water, low dissolved $\mathrm{Fe}$ concentration of $0.29 \mathrm{nmol} \mathrm{L}^{-1}$ was measured according to de Jong et al. (2008) by isotopic dilution combined with multiple collector inductively coupled plasma mass spectrometry (ID-MC-ICP-MS) using nitrilotriacetic acid chelating resin for pre-concentration and matrix separation. The ISPOL water was spiked with chelexed macronutrients to reach final concentrations of $10 \mu \mathrm{mol} \mathrm{L}^{-1} \mathrm{Si}, 10 \mu \mathrm{mol} \mathrm{L}^{-1} \mathrm{NO}_{3}^{-}$, and $1 \mu \mathrm{mol} \mathrm{L}^{-1} \mathrm{PO}_{4}^{3-}$, to avoid growth limitation by a nutrient other than Fe. Fragilariopsis was enriched with additional $\mathrm{Si}$ so as to reach a $\mathrm{Si}: \mathrm{NO}_{3}^{-}$of $6: 1$ (K. Karsh, personal communication, 2008) for optimal growth. Bacterial contamination of the culture was examined using epifluorescence microscope observation (DAPI staining, Porter and Feig, 1980). Cellular concentration, biovolume and derived average spherical diameter were measured by either using a Coulter counter (Multisizer Z3, except for Fragilariopsis) or inverted microscopy (Leitz Fluovert). Cellular volume (V), surface area (A) and surface to volume ratio were calculated according to Hillebrand et al. (1999) using microscopic measurements (Table 1). Calculated cellular biovolumes (Table 1) were statistically identical $(95 \%$ level of confidence) to the volumes determined by Coulter counter for Phaeocystis $\left(58 \pm 23 \mu \mathrm{m}^{3}, n=3\right)$, Chaetoceros $\left(26 \pm 2 \mu \mathrm{m}^{3}, n=3\right)$ and Thalassiosira $\left(2225 \pm 253 \mu \mathrm{m}^{3}, n=5\right)$.

\subsection{Experimental solutions and ligands}

The experimental media consisted of ISPOL filtered water (control treatment), ISPOL filtered water with $1 \mathrm{nmol} \mathrm{L}^{-1} \mathrm{Fe}$ (Fe treatment) and ISPOL filtered water with $1 \mathrm{nmol} \mathrm{L}^{-1} \mathrm{Fe}$ and $15 \mathrm{nmol} \mathrm{L}^{-1}$ of organic ligand. The organic ligands (L) were selected to represent the groups of hydroxamate (desferrioxamine B, DFB) and catecholate (Gallocatechin, CAT) siderophores, porphyrins (protoporphyrin IX, PIX), organic amine (N,N'-Di(2-hydroxybenzyl)ethylenediamineN,N'-diacetic acid monohydrochloride hydrate, HBED) and saccharides (mono-saccharides: D-Galacturonic acid (GAL), D-Glucuronic acid (GLU); polysaccharides: Alginic acid from brown algae (ALG), dextran from Leuconostoc ssp. (DEX, $500000 \mathrm{~g} / \mathrm{mole})$ ). All organic ligands were from Sigma-Aldrich, except HEBD (Strem Chemical). Stock solutions of $1 \mathrm{mmol} \mathrm{L}^{-1}$ were prepared with ultra-pure water (Millipore Element, $18.2 \mathrm{M} \Omega \mathrm{cm}$ ), except for PIX that was prepared in DMSO (JT Baker). Stock solutions were then diluted down to $15 \mu \mathrm{mol} \mathrm{L}^{-1}$ in milliQ water and analysed 
Table 1. Cellular volume (V), surface area (A) and surface area to volume ratio calculated according to Hillebrand et al., 1999 for: Chaetoceros, Thalassiosira present as single cells only, Phaeocystis mainly occurring as single cells (78\%) and Fragilariopsis chains of $28 \pm 12$ cells $(n=23)$.

\begin{tabular}{lrrr}
\hline Strain & Volume $\left(\mu \mathrm{m}^{3}\right) \pm \mathrm{SD}$ & Surface area $\left(\mu \mathrm{m}^{2}\right) \pm \mathrm{SD}$ & $\mathrm{A} / \mathrm{V}\left(\mu \mathrm{m}^{-1}\right) \pm \mathrm{SD}$ \\
\hline Phaeocystis sp. & $69 \pm 33$ & $79 \pm 27$ & $1.25 \pm 0.24$ \\
Chaetoceros sp. & $31 \pm 5$ & $62 \pm 9$ & $2.01 \pm 0.07$ \\
Thalassiosira antarctica & $1747 \pm 353$ & $801 \pm 112$ & $0.47 \pm 0.04$ \\
Fragilariopsis & $218194 \pm 91589$ & $25871 \pm 9969$ & $0.12 \pm 0.01$ \\
kerguelensis (chain) & & & \\
Fragilariopsis kerguelensis (cell) & $8150 \pm 841$ & $3017 \pm 282$ & $0.37 \pm 0.03$ \\
\hline
\end{tabular}

for background Fe contamination by ICP-MS (Perkin Elmer Elan DRC II ICP-MS). When Fe contamination was detected $\left(0.7 \mathrm{nmol} \mathrm{L}^{-1}\right.$ for $15 \mu \mathrm{mol} \mathrm{L}^{-1} \mathrm{DFB}, 16 \mathrm{nmol} \mathrm{L}^{-1}$ for $15 \mu \mathrm{mol} \mathrm{L}^{-1}$ PIX and $0.7 \mathrm{nmol} \mathrm{L}^{-1}$ for $15 \mathrm{nmol} \mathrm{L}^{-1}$ DEX), it was considered in the experimental setup (L equals $15 \mathrm{nmol} \mathrm{L}^{-1}$ ) and calculations. Fe contamination was below detection limit $\left(0.05 \mathrm{nmol} \mathrm{L}^{-1}\right)$ for the other ligands. Stock solutions were stored in the dark at $4^{\circ} \mathrm{C}$ or $-18^{\circ} \mathrm{C}$ (for siderophores).

Since the ISPOL filtered water used was not UV photooxidised, it contains stable organic ligands that can react with the added $\mathrm{Fe}$. In the control treatment, where the quantity of the added $\mathrm{Fe}$ (as ${ }^{55} \mathrm{Fe}$ ) is negligible $(6 \%$ of total dissolved Fe naturally present), the chemical speciation of $\mathrm{Fe}$ should represent its natural distribution (assuming equilibration within $24 \mathrm{~h}$ ). Following the $1 \mathrm{nmol} \mathrm{L}^{-1} \mathrm{Fe}$ addition ( $\mathrm{Fe}$ treatment), weaker Fe-reactive organic ligands will be bound and probably saturated with $\mathrm{Fe}$. The Fe treatment, therefore, corresponds to the amendment of highly reactive organically bound and possibly inorganic $\mathrm{Fe}$.

\subsection{Fe bioaccumulation experiment}

Radiolabelled Fe $\left({ }^{55} \mathrm{Fe}\right.$, PerkinElmer, $82.80 \mathrm{mCi} \mathrm{mg}^{-1}$ as $\mathrm{FeCl}_{3}$ in $0.5 \mathrm{~mol} \mathrm{~L}{ }^{-1} \mathrm{HCl}$ ) was used in bioaccumulation experiments. Radioactive standard solutions of inorganic $\mathrm{Fe}\left(0.7 \mu \mathrm{mol} \mathrm{L}^{-1} \mathrm{Fe}\right.$ and $0.3 \mu \mathrm{mol} \mathrm{L}^{-1}{ }^{55} \mathrm{Fe}$ in $\left.0.01 \mathrm{~mol} \mathrm{~L}^{-1} \mathrm{HCl}\right)$ and organic $\mathrm{Fe}\left(0.7 \mu \mathrm{MFe}, 0.3 \mu \mathrm{M}^{55} \mathrm{Fe}\right.$, $15 \mu \mathrm{ML}$ ) were prepared one week in advance to reach equilibrium and stored in the dark at $4^{\circ} \mathrm{C}$. Radioactive stock solutions were 1000 -fold diluted into ISPOL filtered water $\left(1.6 \mathrm{nCi} \mathrm{mL}^{-1}\right)$ and kept in the dark at $2^{\circ} \mathrm{C}$ for $24 \mathrm{~h}$ to reach equilibrium. In the control treatment, only $0.08 \mathrm{nCi} \mathrm{mL}^{-1}$ of ${ }^{55} \mathrm{Fe}$ were added corresponding to negligible $\mathrm{Fe}$ enrichment $(6 \%)$. For each experimental solution, two $\mathrm{mL}$ were taken to determine the total initial ${ }^{55} \mathrm{Fe}$ content.

Following the equilibration phase, microorganisms were directly added into the radioactive experimental solution so as to reach a final abundance of 10000 cells $\mathrm{mL}^{-1}$ for Phaeocystis sp. and Chaetoceros sp. and 1000 cells mL $\mathrm{mL}^{-1}$ for Thalassiosira antarctica and Fragilariopsis kerguelensis. They were then incubated for $16 \mathrm{~h}$ at $2^{\circ} \mathrm{C}$ and constant light $\left(120 \mu \mathrm{mol}\right.$ photons $\mathrm{m}^{-2} \mathrm{~s}^{-1}$ for Phaeocystis and $60 \mu$ mol photons $\mathrm{m}^{-2} \mathrm{~s}^{-1}$ for diatoms). After $16 \mathrm{~h}$ incubation, the algal suspensions were transferred in the dark at $4^{\circ} \mathrm{C}$ and were immediately processed. Ten $\mathrm{mL}$ of the solution was successively filtered using a syringe with $0.2 \mu \mathrm{m}$ and $0.02 \mu \mathrm{m}$ filters (Anatop, Whatman) to determine dissolved and soluble $\mathrm{Fe}$, respectively. The remainder of the sample was divided into two parts: one was gently filtered ( $<5 \mathrm{~mm} \mathrm{Hg}, 0.45 \mu \mathrm{m}$, nitrocellulose, Sartorius) for the measurement of the total cellular Fe. Oxalate solution (TovarSanchez et al., 2003; Tang and Morel, 2006; Hassler and Schoemann, 2009) was directly added in a 1:10 v:v to the second portion of the sample. This solution was kept in the dark at $4^{\circ} \mathrm{C}$ for $20 \mathrm{~min}$ prior to being filtered $(<5 \mathrm{~mm} \mathrm{Hg}$, $0.45 \mu \mathrm{m}$ ) for the determination of intracellular Fe. Following filtration, filters were rinsed 3-times with non-radioactive saline solution $\left(0.6 \mathrm{~mol} \mathrm{~L}^{-1} \mathrm{NaCl}, 2.38 \mathrm{mmol} \mathrm{L}^{-1} \mathrm{NaHCO}_{3}\right.$, Tang and Morel, 2006). This procedure was shown to be effective in removing extracellular Fe from Chaetoceros sp., Phaeocystis sp. and natural assemblages from the SO without biologically deleterious effects (Hassler and Schoemann, 2009). The extracellular iron could be either associated to binding sites or simply adsorbed to the surface of the cell. Radioactive Fe solutions and filters were collected in scintillation vials with $10 \mathrm{~mL}$ scintillation cocktail (Ultima Gold, Perkin Elmer), vortexed and measured using a liquid scintillation analyzer (Perkin Elmer Tri-Carb 2100TR). Each sample was analysed three times in presence of four blanks of either non-radioactive seawater or filter. Typical values of blanks were 6 and 10 counts per minutes (cpm) for seawater and filters, respectively. The averaged value of the blanks was subtracted to the cpm obtained in the sample. Counts per minutes were then converted into disintegration per minutes (dpm) taking into account the radioactive decay and custom quench curves. Counting errors were $<3 \%$ and maximum standard deviations of $1 \%$ and $5 \%$ were obtained for seawater and filter samples, respectively. The uptake of radioactive $\mathrm{Fe}$ (dpm) was related to Fe concentrations using the sum of 
the dissolved $\mathrm{Fe}$ concentration measured in the ISPOL filtered water and the nominal $\mathrm{Fe}$ addition. Extracellular $\mathrm{Fe}$ concentrations were calculated as the difference between total cellular Fe and intracellular Fe. Experiments were done in duplicates.

$\mathrm{Fe}$ concentrations were normalised against incubation time and cell number and are expressed in amol $\mathrm{Feh}^{-1}$ cell $^{-1}$. $\quad \mathrm{Fe}$ cellular concentrations were also normalised by cellular volume $(\mathrm{V})$, surface area $(\mathrm{A})$, and surface area to volume ratio (A/V).

An experiment was done without any microorganisms in order to measure the effect of organic ligand alone on Fe size fractionation (dissolved $(<0.2 \mu \mathrm{m})$, soluble $(<0.02 \mu \mathrm{m})$, and particulate $(>0.2 \mu \mathrm{m}) \mathrm{Fe}$ ). Loss of Fe due to adsorption on the wall of the containers used was negligible $(<5 \%)$ during the $24 \mathrm{~h}$ equilibration phase, as well as during the $16 \mathrm{~h}$ incubation.

\subsection{Carbon uptake and Fe:C uptake ratio}

In parallel to Fe bioaccumulation experiments, carbon uptake was measured following $2 \mathrm{~h}$ and $16 \mathrm{~h}$ incubations in 50 to $100 \mathrm{~mL}$ samples. The $2 \mathrm{~h}$ incubation was conducted to measure the photosynthetic carbon fixation and to minimize radiocarbon losses by respiration whereas the $16 \mathrm{~h}$ incubation was done to compare with the longer incubation time needed with ${ }^{55} \mathrm{Fe}$ to achieve better sensitivity. Radioactive carbon was added at a final concentration of $100 \mu \mathrm{Ci} \mathrm{L}^{-1}$ sodium ${ }^{14} \mathrm{C}$ bicarbonate to $0.2 \mu \mathrm{m}$ filtered water from ISPOL prior to the addition of microorganisms (see $\mathrm{Fe}$ bioaccumulation for details). The phytoplankton was then incubated in the same conditions as for $\mathrm{Fe}$ bioaccumulation. Cells were collected by gentle filtration $(<5 \mathrm{~mm} \mathrm{Hg}, 25 \mathrm{~mm} 0.8 \mu \mathrm{m}$ Millipore polycarbonate filter) and rinsed with saline solution $\left(0.6 \mathrm{~mol} \mathrm{~L}^{-1} \mathrm{NaCl}, 2.38 \mathrm{mmol} \mathrm{L}^{-1} \mathrm{NaHCO}_{3}\right.$, Tang and Morel, 2006). Organic carbon fixation was differentiated using acidification $\left(100 \mu 10.1 \mathrm{~mol} \mathrm{~L}^{-1} \mathrm{HCl}\right)$ of particulate material (see Schoemann et al., 2001). The ${ }^{14} \mathrm{C}$ radioactivity was determined by liquid scintillation with a Perkin Elmer (Tri-Carb 2100TR) analyser after the addition of the scintillation cocktail (EcoLume, MP Biomedicals). Experiments were done in duplicate. $\mathrm{Fe}: \mathrm{C}$ uptake ratio was calculated using the $2 \mathrm{~h}$ and $16 \mathrm{~h}$ carbon uptake (or assimilation) and the total and intracellular iron uptake rates.

\subsection{Precautions to avoid contamination and statistical test}

No bacteria were observed by DAPI stain and epifluorescence microscopy (Porter and Feig, 1980) in the ISPOL filtered water, the cultures used or the experimental final biomass controls. All culture manipulation and solution preparation were done in a class-100 laminar flow bench following trace-metal-clean and sterility procedures. All containers and filters used, prior to radioactive data collection were made of polycarbonate (Nalgene, Millipore) and were acid washed $\left(1 \mathrm{~mol} \mathrm{~L}^{-1} \mathrm{HCl}\right)$. Pipette tips were acid-cleaned with $6 \mathrm{~mol} \mathrm{~L}^{-1}$ ultrapure $\mathrm{HCl}$ (Seastar). After acid cleaning, all material was thoroughly rinsed with ultra-pure water (Millipore, milli-Q Element).

The significance of the differences between treatments was assessed using a two-tailed paired student $\mathrm{t}$-test at the $95 \%$ confidence level.

\section{Results}

\subsection{Fe bioaccumulation - Fe enrichment}

Compared to the control treatment, the addition of $1 \mathrm{nmol} \mathrm{L}-1$ Fe resulted in increased intracellular Fe uptake rates for all strains (Fig. 1a). The extracellular to intracellular $\mathrm{Fe}$ pool ratio $\left(\mathrm{Fe}_{\mathrm{ext}}: \mathrm{Fe}_{\text {int }}\right)$, gives information on the cellular $\mathrm{Fe}$ distribution. A Fe $\mathrm{ext}: \mathrm{Fe}_{\text {int }}$ ratio of 1 means that $\mathrm{Fe}$ is equally distributed between the intracellular and extracellular pools, whereas a $\mathrm{Fe}_{\mathrm{ext}}: \mathrm{Fe}_{\text {int }}>1$ means that $\mathrm{Fe}$ is predominantly associated with the extracellular fraction. Most of the cellular $\mathrm{Fe}\left(\mathrm{Fe}_{\mathrm{ext}}: \mathrm{Fe}_{\text {int }}>1\right)$ is associated with extracellular binding sites (Fig. 1b). The $\mathrm{Fe}_{\text {ext }}: \mathrm{Fe}_{\text {int }}$ ratio is nearly constant for all strains in the control treatment (Chaetoceros, 1.6; Phaeocystis, 1.6; Thalassiosira, 1.2; Fragilariopsis, 1.8). Except for Thalassiosira (0.9), this ratio increases for all strains after the addition of $1 \mathrm{nMFe}$, attesting that higher increases are generally observed in the extracellular pool than in the intracellular pool as a result of $\mathrm{Fe}$ enrichment. The chain forming diatom Fragilariopsis has the highest ratio (6.9) followed by Chaetoceros (5.4) and Phaeocystis (3.5).

For all treatments (except in the case of extracellular Fe for Fragilariopsis), intracellular and extracellular Fe per cell follow the order: Chaetoceros sp. $<$ Phaeocystis sp. $<$ Fragilariopsis kerguelensis $<$ Thalassiosira antarctica. A maximal variation in cellular $\mathrm{Fe}_{\text {int }}$ and $\mathrm{Fe}_{\text {ext }}$ of 2.4-fold is observed for small single cells such as Chaetoceros and Phaeocystis, whereas it is 18.5-fold within all the strains studied (Fig. 1a, c, Table 1, Supplement, see http://www.biogeosciences.net/ 6/2281/2009/bg-6-2281-2009-supplement.pdf). However, the variability of the cellular Fe between strains was the smallest when $\mathrm{Fe}$ was normalised against the surface area (Fig. 1b). In this case, the difference between all single cells decreased and a maximal variation of 6.5 -fold for $\mathrm{Fe}_{\text {int }}$ and $\mathrm{Fe}_{\text {ext }}$ is observed in between diatoms and Phaeocystis, with a minimal variation between the three diatoms of 1.1fold (Table 1, Supplement, see http://www.biogeosciences. net/6/2281/2009/bg-6-2281-2009-supplement.pdf). Cellular Fe normalized against the surface area follows the order Phaeocystis $>$ Chaetoceros $\geq$ Thalassiosira $\geq$ Fragilariopsis. A maximal variation between cellular Fe normalised against $\mathrm{V}$ and $\mathrm{A} / \mathrm{V}$ of 70 and 2717-fold, respectively was observed for the four selected strains (Ta- 


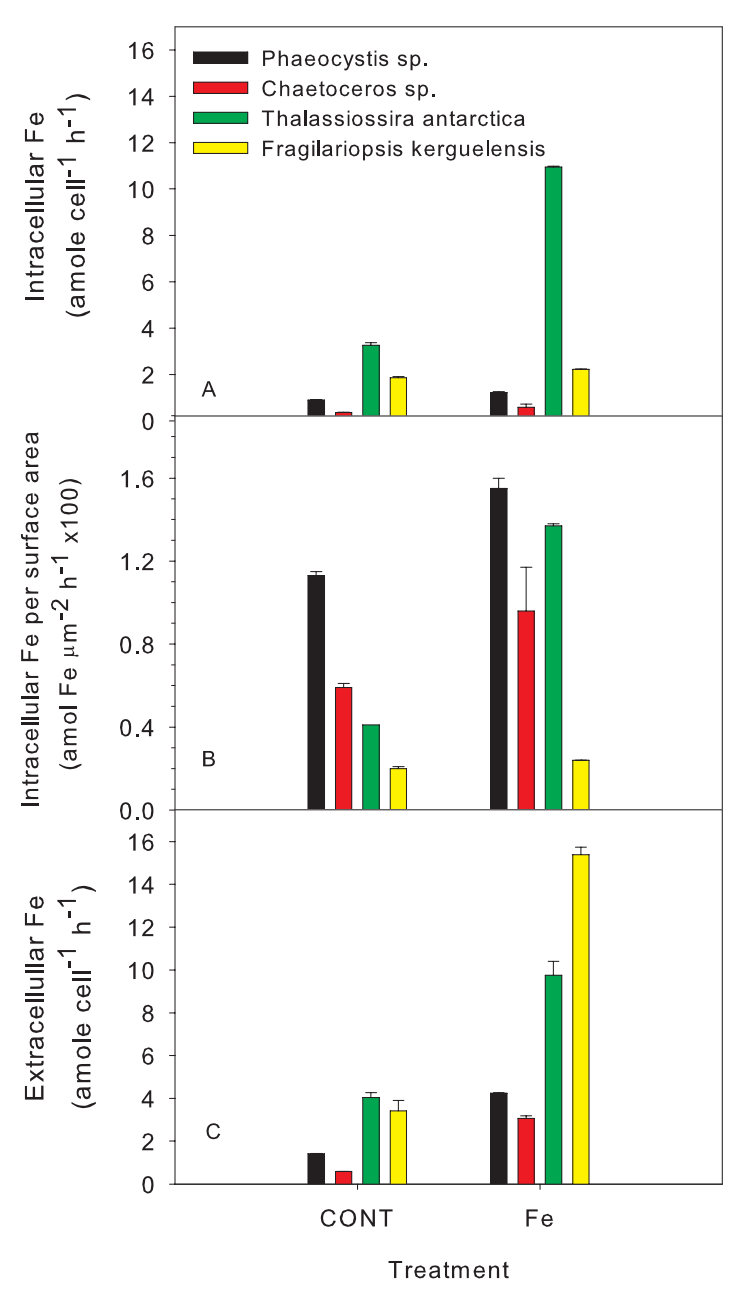

Fig. 1. Intracellular Fe uptake rates per cell (A) and per surface area (B) for Phaeocystis sp., Chaetoceros sp., Thalassiosira antarctica and Fragilariopsis kerguelensis in ISPOL filtered water (CONT treatment) and with $1 \mathrm{nmol} \mathrm{L}^{-1} \mathrm{Fe}$ enriched ISPOL seawater (Fe treatment). For Fragilariopsis, given that not all cell surface contribute to Fe uptake, intracellular Fe uptake rate per chain was normalised against the surface area of the chains. Extracellular Fe per cell is also shown (C) for both experimental treatments. Error bars represent half of data interval $(n=2)$.

ble 1, Supplement, see http://www.biogeosciences.net/6/ 2281/2009/bg-6-2281-2009-supplement.pdf).

\subsection{Fe bioaccumulation - excess of organic ligands}

The addition of $1 \mathrm{nmol} \mathrm{L}^{-1} \mathrm{Fe}$ with $15 \mathrm{nmol} \mathrm{L}^{-1}$ of various organic ligands resulted in different effects on the intracellular Fe uptake rates as compared to the intracellular Fe uptake rates after the addition of $1 \mathrm{nmol} \mathrm{L}^{-1} \mathrm{Fe}$ without any amendment of organic ligand (Fig. 2a). The hydroxamate siderophore DFB and organic amine HBED strongly decreased Fe bioavailability, whereas no statistical effect (at the 0.05 level) was observed for the catecholate siderophore CAT for all the strains studied (Fig. 2a, except for Chaetoceros). The addition of $\mathrm{Fe}$ bound to a tetrapyrole (PIX) resulted either in no statistical change (Thalassiosira, level of 0.05) or in an increase (Phaeocystis, Chaetoceros, Fragilariopsis) in intracellular Fe uptake rates.

The presence of excess mono- (GAL, GLU) and polysaccharides (ALG, DEX) generally resulted in increased intracellular and extracellular Fe uptake rates for Chaetoceros, Phaeocystis and Fragilariopsis (Fig. 2a and b). Except from a slight decrease of intracellular Fe uptake in the presence of DEX, the addition of saccharides had no significant effects on Fe uptake rates of Thalassiosira.

The organic ligands amendments have similar effects on intracellular and extracellular Fe (Fig. 2b), except for ALG for Thalassiosira and Fragilariopsis where a disproportionate increase of extracellular Fe was measured (see below). The $\mathrm{Fe}_{\text {ext }}: \mathrm{Fe}_{\text {int }}$ ratio was relatively constant for all treatments (except ALG for Thalassiosira and Fragilariopsis). Most of the variation was found between strains. For each strain, $\mathrm{Fe}_{\text {ext }}: \mathrm{Fe}_{\text {int }}$ ratios were similar in presence and absence of ligands. Ratios were $2.6 \pm 0.8$ for Phaeocystis, $4.2 \pm 1.5$ for Chaetoceros, $1.0 \pm 0.2$ for Thalassiosira (but 5.6 for ALG), $6.0 \pm 1.7$ for Fragilariopsis (but 25.3 for ALG).

\subsection{Fe size distribution}

The addition of ligands will affect Fe chemical speciation, but also its overall solubility. In this study, Fe solubility was assessed by discriminating between particulate $(>0.2 \mu \mathrm{m})$, colloidal Fe $(0.02-0.2 \mu \mathrm{m})$ and soluble Fe $(<0.02 \mu \mathrm{m})$ following successive filtration of the Antarctic seawater (Fig. 3) in the absence of microorganism.

In the control treatment, most of the Fe stays in the dissolved phase $(>70 \%,<0.2 \mu \mathrm{m})$ with $39 \%$ soluble and $33 \%$ colloidal. The addition of $1 \mathrm{nmol} \mathrm{L}-1$ Fe increased the concentration of particulate $\mathrm{Fe}$ from 29 to $56 \%$. In the Fe treatment, both soluble (28\%) and colloidal (16\%) Fe decreased as compared to the control.

For an addition of $1 \mathrm{nmol} \mathrm{L}^{-1} \mathrm{Fe}$ together with the organic ligands, particulate Fe remains lower than in the Fe treatment, except in presence of ALG. In presence of DFB and HEBD, Fe is fully relocated within the soluble phase. For the other ligands (except ALG), the soluble and colloidal Fe fraction is increased as compared to the Fe treatment, to a level close to what is observed in natural water (control treatment). The aggregation of $\mathrm{Fe}$ in the presence of ALG could explain the disproportionately high and variable extracellular $\mathrm{Fe}$ observed in the case of Thalassiosira and Fragilariopsis as abiotic particulate $\mathrm{Fe}$ can become significant as compared to the biotic Fe (Fig. 2b).

In presence of microorganisms, abiotic to biotic particulate $\mathrm{Fe}$ cannot be differentiated when total Fe uptake is being determined. However, similar trends in soluble and colloidal $\mathrm{Fe}$ were observed. For example, the addition of $1 \mathrm{nmol} \mathrm{L}^{-1} \mathrm{Fe}$ resulted in a decrease of both averaged colloidal $(27 \%$ in 


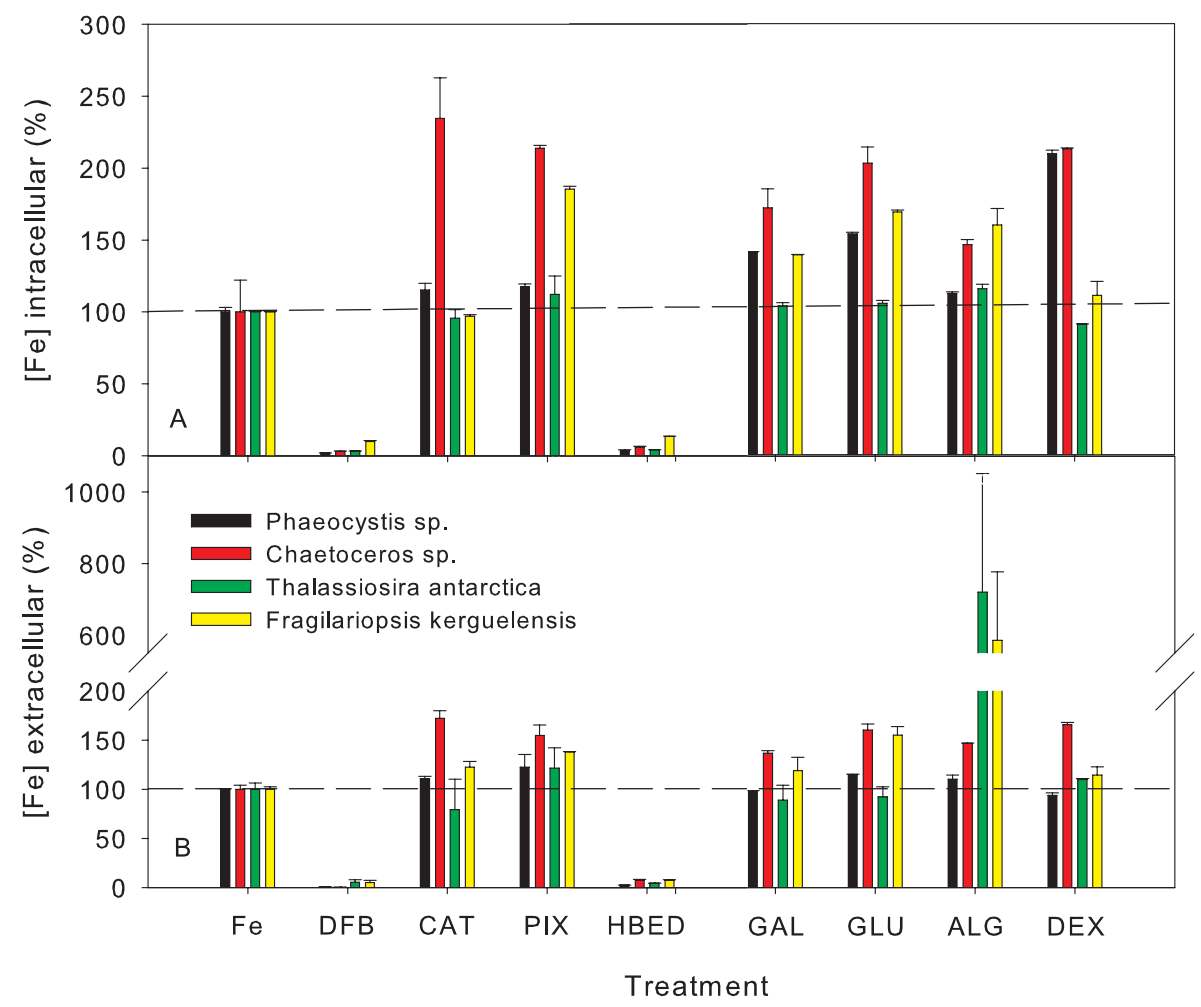

Fig. 2. Intracellular Fe uptake rates (A) and extracellular Fe (B) for Phaeocystis sp., Chaetoceros sp., Thalassiosira antarctica and Fragilariopsis kerguelensis in filtered Antarctic seawater enriched with $1 \mathrm{nmol} \mathrm{L}-1$ Fe (Fe treatment) and $15 \mathrm{nmol} \mathrm{L}-1$ organic ligands. The organic ligands studied were desferrioxamine B (DFB), Gallocatechin (CAT), protoporphyrin IX (PIX), N,N'-Di(2-hydroxybenzyl)ethylenediamineN,N'-diacetic acid monohydrochloride hydrate (HBED), D-Galacturonic acid (GAL), D-Glucuronic acid (GLU), Alginic acid from brown algae (ALG), and dextran from Leuconostoc ssp. (DEX). Both intracellular and extracellular Fe were expressed in \% of the Fe treatment (without any addition of organic ligands) on a cellular basis. Dash line represents results for the Fe treatment (100\%). Error bars represent half of data interval $(n=2)$.

Table 2. Iron to carbon ratio ( $\mu \mathrm{mol}$ :mol) for the four strains studied: Phaeocystis sp., Chaeotoceros sp., Thalassiosira antarctica Comber, and Fragilariopsis kerguelensis. Mean values $(n=4)$ are given with standard deviation for the control $(\mathrm{C})$ and $\operatorname{addition}$ of $1 \mathrm{nmol} \mathrm{L}^{-1} \mathrm{Fe}(\mathrm{Fe})$ experimental treatments. Ratios are calculated considering either total cellular $\mathrm{Fe}\left(\mathrm{Fe}_{\text {tot }}\right)$ or intracellular $\mathrm{Fe}\left(\mathrm{Fe}_{\text {int }}\right)$ uptake rates and short term $(2 \mathrm{~h})$ carbon uptake rates. The statistical difference in the Fe:C ratios between the two experimental treatments is shown in italic ( $\mathrm{p}$ value of paired t-test).

\begin{tabular}{lrrrrr}
\hline Treatment & Parameter & Phaeocystis & Chaetoceros & Thalassiosira & Fragilariopsis \\
\hline CONT & $\mathrm{Fe}_{\text {int }}: \mathrm{C}$ & $14.7 \pm 1.0$ & $19.1 \pm 0.8$ & $3.5 \pm 0.2$ & $0.8 \pm 0.1$ \\
& & 0.0001 & 0.3122 & $<0.0001$ & 0.0010 \\
& $\mathrm{Fe}_{\text {tot }}: \mathrm{C}$ & $23.4 \pm 1.9$ & $49.0 \pm 1.2$ & $7.8 \pm 0.3$ & $2.2 \pm 0.2$ \\
& & 0.0037 & 0.0050 & $<0.0001$ & $<0.0001$ \\
$\mathrm{Fe}$ & $\mathrm{Fe}_{\text {int }}: \mathrm{C}$ & $21.4 \pm 1.2$ & $23.5 \pm 8.1$ & $11.0 \pm 0.2$ & $1.0 \pm 0.1$ \\
& $\mathrm{Fe}_{\mathrm{tot}}: \mathrm{C}$ & $74.8 \pm 4.0$ & $154.6 \pm 32.6$ & $20.8 \pm 0.9$ & $8.1 \pm 0.6$ \\
\hline
\end{tabular}

CONT down to $16 \%$ in the Fe treatment) and soluble (35\% in CONT down to 5\% in the Fe treatment) Fe. The addition of DFB and HBED relocated the Fe (not already associated with phytoplankton) into the soluble fraction. In presence of the other ligands, both soluble and colloidal Fe, were higher than in the Fe treatments.

\subsection{Carbon fixation}

The carbon uptake rates per cell were contrasted for the various studied strains (e.g. variation of 126-fold for the $2 \mathrm{~h}$ incubation) and follow the order: Chaetoceros $\left(28.9 \pm 7.5 \mathrm{fmolC} \mathrm{cell}^{-1} \mathrm{~h}^{-1}\right)<$ Phaeocystis $\quad(65.9$ 


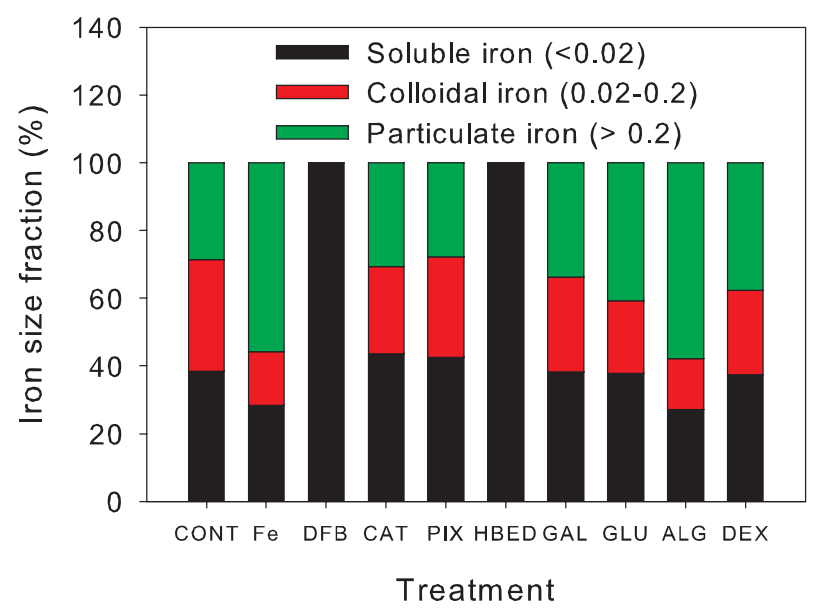

Fig. 3. Average Fe size distribution following successive filtration on 0.2 and $0.02 \mu \mathrm{m}$ of the seawater in absence of microorganisms. Colloidal $\mathrm{Fe}$ is defined as $<0.2-0.02 \mu \mathrm{m}$ and soluble $\mathrm{Fe}$ as $<0.02 \mu \mathrm{m}$. Experimental treatments are filtered Antarctic seawater without (CONT) and with an Fe enrichment $\left(1 \mathrm{nmol} \mathrm{L}^{-1}\right.$, $\mathrm{Fe}$ ); an $\mathrm{Fe}$ enrichment together with $15 \mathrm{nmol} \mathrm{L}^{-1}$ organic ligands: desferrioxamine B (DFB), Gallocatechin (CAT), protoporphyrin IX (PIX), N,N'-Di(2-hydroxybenzyl)ethylenediamineN,N'-diacetic acid monohydrochloride hydrate (HBED), DGalacturonic acid (GAL), D-Glucuronic acid (GLU), Alginic acid (ALG) and dextran (DEX).

$\left.\pm 13.0 \mathrm{fmolC} \mathrm{cell}^{-1} \mathrm{~h}^{-1}\right) \quad<$ Thalassiosira $\quad(1059.8 \pm$ $\left.121.0 \mathrm{fmolC} \mathrm{cell}^{-1} \mathrm{~h}^{-1}\right) \quad<$ Fragilariopsis $\quad(2828.5 \pm$ $597.0 \mathrm{fmolC} \mathrm{cell}^{-1} \mathrm{~h}^{-1}$ ). Normalisation of carbon uptake by cell volume gives the lowest variability in carbon uptake between the strains selected. For carbon uptake normalised per unit volume, only a two-fold variation was observed between all the diatoms. This small variation shows that the large differences observed at the cellular level can largely be attributed to differences in cell volume. Phaeocystis has the highest $\mathrm{C}$ uptake per unit of cell volume (1.4 to 2.9-fold higher than for diatoms, Table 2, Supplement, see http://www.biogeosciences.net/6/2281/ 2009/bg-6-2281-2009-supplement.pdf), which can be only partly due to the carbon allocated to the production of mucus in the colonies since cells were predominantly in the solitary form under our experimental conditions. The maximal inter-strain variation of carbon uptake normalised against $\mathrm{A}$ and $\mathrm{A} / \mathrm{V}$, were 8.4 and 58700 -fold, respectively (Table 2, Supplement, see http://www.biogeosciences.net/6/ 2281/2009/bg-6-2281-2009-supplement.pdf).

The presence of $1 \mathrm{nmol} \mathrm{L}^{-1} \mathrm{Fe}$ or $1 \mathrm{nmol} \mathrm{L}^{-1} \mathrm{Fe}$ with organic ligands did not statistically affect carbon fixation. No statistical difference $(p>0.05)$ was observed between carbon cellular uptake rate following both $2 \mathrm{~h}$ and $16 \mathrm{~h}$ incubations for the three tested diatoms. In the control treatment, carbon uptake rate following $16 \mathrm{~h}$ was between 1.4-fold smaller to 1.2-fold higher than the uptake rate measured following $2 \mathrm{~h}$ incubation. An experimental problem prevented us to measure carbon uptake following $16 \mathrm{~h}$ incubation for Phaeocystis.

\subsection{Fe to carbon ratio}

Both $\mathrm{Fe}$ and $\mathrm{C}$ uptake rates per cell follow the same order for Chaetoceros, Phaeocystis and Thalassiosira. Fragilariopsis has by far the highest carbon uptake rate but has the third highest Fe uptake rate. Because of a small difference of Fe uptake rates (e.g. 9-fold in the control treatment, Fig. 1) as compared to carbon uptake rates (e.g. 126fold in the control treatment, Fig. 4) for the strains studied, the $\mathrm{Fe}$ to carbon ratio is also quite variable (20 to 25-fold, Table 2). Fe:C ratios were calculated both considering intracellular $\mathrm{Fe}$ only and considering total (intracellular+extracellular) $\mathrm{Fe}$ uptake. The $\mathrm{Fe}: \mathrm{C}$ ratios are reported here for both control and $1 \mathrm{nmolL}^{-1} \mathrm{Fe}$ addition treatments. Fe:C ratios are ranked as follows: Chaetoceros $>$ Phaeocystis $>$ Thalassiosira $>$ Fragilariopsis. Because of a higher $\mathrm{Fe}$ uptake rates but identical carbon uptake rates in presence of $1 \mathrm{nmol} \mathrm{L}^{-1} \mathrm{Fe}$ as compared to the control treatment on the incubation time of the experiment, $\mathrm{Fe}: \mathrm{C}$ were statistically higher for the $\mathrm{Fe}$ treatment (except for Chaetoceros considering $\mathrm{Fe}_{\text {int }}$ ). Similar results were obtained with $\mathrm{Fe}_{\text {int }}: \mathrm{C}$ uptake ratio using the carbon uptake rate measured following $16 \mathrm{~h}$ incubation. For the control treatment, the short-term $\mathrm{Fe}: \mathrm{C}$ ratios calculated using the $16 \mathrm{~h}$ carbon uptake data were $27.7 \pm 3.3 \mu \mathrm{mol}: \mathrm{mol}$ for Chaetoceros, $3.2 \pm 0.1 \mu \mathrm{mol}: \mathrm{mol}$ for Thalassiosira, and $0.7 \pm 0.1 \mu \mathrm{mol}$ :mol for Fragilariopsis. A $1 \mathrm{nmol} \mathrm{L}^{-1} \mathrm{Fe}$ addition resulted in $\mathrm{Fe}: \mathrm{C}$ uptake ratio increased as a consequence of $\mathrm{Fe}$ uptake increase and no difference of carbon uptake on the time scale of our experiment (for Chaetoceros: 46.4 $\pm 11.8 \mu \mathrm{mol}: \mathrm{mol} ;$ Thalassiosira: $14.9 \pm 1.4 \mu \mathrm{mol}: \mathrm{mol}$; and Fragilariopsis: $1.6 \pm 0.3 \mu \mathrm{mol}: \mathrm{mol})$.

\section{Discussion}

\subsection{Fe bioavailability to Antarctic phytoplankton}

In this study, the bioavailability of organic forms of $\mathrm{Fe}$ is related to $\mathrm{Fe}$ intracellular uptake rates. The addition of $\mathrm{Fe}\left(1 \mathrm{nmol} \mathrm{L}^{-1}\right)$ resulted in increased bioavailability as attested by higher intracellular and extracellular $\mathrm{Fe}$ for all strains. The intracellular Fe uptake rates $(0.4$ to $\left.3.3 \times 10^{-18} \mathrm{~mol} \mathrm{cell}^{-1} \mathrm{~h}^{-1}\right)$ and the corresponding $\mathrm{Fe}_{\mathrm{ext}}: \mathrm{Fe}_{\text {int }}$ ratio (1.2-1.8) in the Antarctic seawater (control treatment), are similar to those previously obtained (e.g. Hudson and Morel, 1989; Hutchins et al., 1999). The increase in iron cellular pools for $1 \mathrm{nmol} \mathrm{L}^{-1} \mathrm{Fe}$ addition also suggested that both transport and non-specific Fe cellular sites are not saturated in the control treatment for all the studied strains (e.g. Wilkinson and Buffle, 2004). 


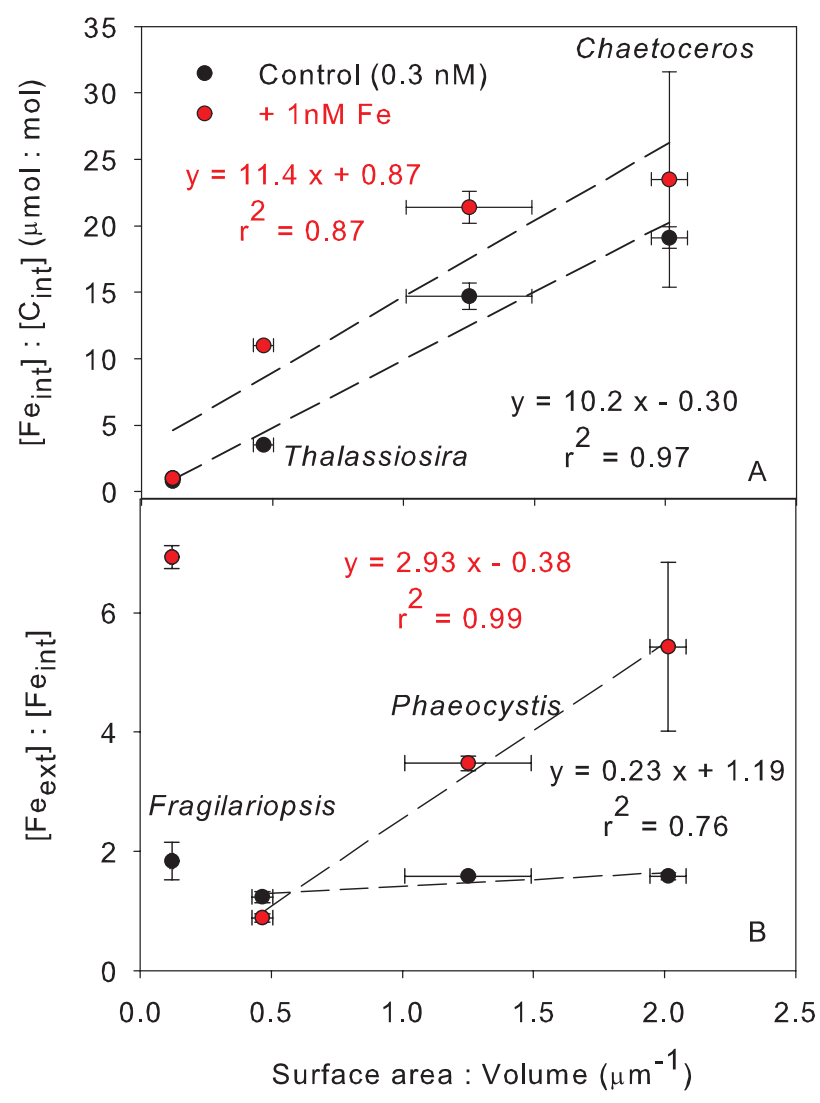

Fig. 4. Influence of the cellular surface area to volume ratio (A/V) on the $\mathrm{Fe}$ to carbon ratio $(\mathrm{Fe}: \mathrm{C}, \mathbf{A})$ and the cellular $\mathrm{Fe}$ distribution ([Fe] extracellular:[Fe] intracellular, B). Error bars represent standard deviation $(n \geq 4)$. Results for linear regression are shown in the figure.

In this study, intracellular and extracellular Fe pools were normalised in an attempt to identify parameters explaining the variability of Fe uptake for Antarctic phytoplankton. The least variability was observed when Fe pool was normalised per cellular surface area as compared to the normalisation per volume or per surface to volume ratio. For Fe normalised per surface area, the maximal difference was observed between Phaeocystis and large diatoms, with both intracellular and extracellular Fe per surface area being the highest for Phaeocystis, suggesting a higher affinity for Fe binding for Phaeocystis than for diatoms.

\subsection{Fe to carbon ratio for Antarctic phytoplankton}

Previous studies reported Fe:C for Fe limited Southern Ocean natural phytoplankton between 1 and $20 \mu \mathrm{molFe}: m o l C$ (Abraham et al., 2000; Twining et al., 2004; McKay et al., 2005; Hassler and Schoemann, 2009), well in accordance to the Fe:C ratios observed in our study (Table 2 ). In addition, low $\mathrm{Fe}: \mathrm{C}$ ratio $(<1)$ were also previously reported (Schmidt and Hutchins, 1999;
Maldonado and Price, 1996). Because steady-state Fe:C can be quite different than short term uptake $\mathrm{Fe}: \mathrm{C}$, the $\mathrm{Fe}: \mathrm{C}$ ratio determined in this study were not used to discuss $\mathrm{Fe}$ biological requirement or strength of limitation.

In this study, intracellular $\mathrm{Fe}$ to carbon uptake ratios are proportional to surface area to volume ratios (Fig. 4a), suggesting that $\mathrm{A} / \mathrm{V}$ can be an important factor in determining their short-term Fe:C. Since a Fe enrichment of $1 \mathrm{nmol} \mathrm{L}^{-1}$ increased Fe uptake (except for Fragilariopsis, see below), but did not affect $\mathrm{C}$ uptake following a 16-h incubation, linear relationship is maintained with little change in the slope but a higher intercept. Although higher $\mathrm{Fe}: \mathrm{C}$ was previously reported for picoplankton as compared to larger phytoplankton in subantarctic waters (Twining et al., 2004; McKay et al., 2005), further studies are required to verify the robustness of such relationship in the SO. In addition, other factors have previously been recognised to affect $\mathrm{Fe}: \mathrm{C}$ ratio, such as the provenance of the species (neritic vs pelagic, e.g. Sunda and Huntsman, 1995; Maldonado and Price, 1996), growth irradiance (Sunda and Huntsman, 1997; Strzepek and Harrison, 2004), iron limitation and requirement (e.g. Maldonado and Price, 2001).

\subsection{Limiting step for Fe bioavailability - ecological im- plications for Antarctic phytoplankton}

For a given chemical composition, the following situations - diffusion limited transport, fast uptake processes, and low affinity for extracellular binding sites - all favoured a lower ratio between the extracellular and intracellular $\mathrm{Fe}$ pools (Wilkinson and Buffle, 2004). Comparison of $\mathrm{Fe}$ and control treatments showed that in the presence of $1 \mathrm{nmol} \mathrm{L}^{-1} \mathrm{Fe}$, a larger increase of extracellular than intracellular $\mathrm{Fe}$ was observed for all strains except Thalassiosira, resulting in an increased $\mathrm{Fe}_{\text {ext }}: \mathrm{Fe}_{\text {int }}$ ratio. This suggests that the diffusion of Fe does not limit Fe biological intracellular uptake in the control treatment for Fragilariopsis, Chaetoceros and Phaeocystis. Since the highest intracellular Fe uptake rates were measured for Thalassiosira, a fast Fe uptake could be the cause of the low $\mathrm{Fe}_{\text {ext }}: \mathrm{Fe}_{\text {int }}$ ratio observed. In this case, Thalassiosira antarctica is able to take up $\mathrm{Fe}$ at the limit of its diffusive supply, it is, thus, expected to rapidly respond to environmental changes. Interestingly, chain-forming diatom Fragilariopsis, which is more prone to diffusion limitation (Pahlow et al., 1997), does not appear to be strongly diffusion limited here, because the $\mathrm{Fe}_{\mathrm{ext}}$ : $\mathrm{Fe}_{\text {int }}$ ratio increases upon $\mathrm{Fe}$ enrichment. Fragilariopsis has the highest $\mathrm{Fe}_{\text {ext }}: \mathrm{Fe}_{\text {int }}$, which could result from either strong extracellular binding affinity or a small rate of intracellular $\mathrm{Fe}$ uptake. Fragilariopsis has the lowest $\mathrm{Fe}_{\text {int }} / \mathrm{A}$ in this study. A $1 \mathrm{nmol} \mathrm{L}-1$ Fe enrichment resulted in the smallest increase in extracellular $\mathrm{Fe}$ as compared to the other tested species (probably as a result of lower diffusive supply, Pahlow et al., 1997) but also the smallest increase in intracellular $\mathrm{Fe}$ (which could result from a lowered $\mathrm{Fe}$ requirement in response to strong Fe limitation, Sunda and 
Huntsman, 1995). Under these circumstances, Fragilariopsis is expected to slowly respond to changes in environmental conditions and longer-term, sustained, Fe enrichment might be required for Fragilariopsis to bloom.

It has been recognised that large diatoms are responsive to large-scale in-situ (de Baar et al., 2005) and bottle (Takeda et al., 1998) iron artificial fertilisation. Fragilariopsis sp. and Fragilariopsis kerguelensis were reported as being dominant (and blooming) in naturally iron-enriched region of the ocean such as the Polar Front region (de Baar et al., 1997), continental margin-enriched region of the subarctic Pacific (Lam et al., 2006), and the Kerguelen region (Armand et al., 2008; Timmermans et al., 2008). In the Kerguelen region, Thalassiosira antarctica was dominating in all locations during the KEOPS study (Armand et al., 2008). It is to be noted that four iron infusions were enough during the SOIREE experiment to induce a shift in phytoplankton community towards Fragilariopsis kerguelensis after 6 days (Boyd et al., 2000).

In contrast, Chaetoceros sp. and Phaeocystis sp., mainly present as solitary cells, did not appear strongly Fe-limited in our experiment. These strains should not be easily Felimited as a result of high Fe diffusive supply because of their small size (as single cells), and higher surface to volume ratio (Pahlow et al., 1997), which would lead to lower Fe growth saturation constant as compared to the other studied strains (Timmermans et al., 2001, 2004). For this reason, these strains are expected to be widespread and blooming in Fe-limited regions of the Southern Ocean. Small diatoms (e.g. Chaetoceros from this study) and Phaeocystis are found in most of the Southern Ocean (Sarthou et al., 2005; Schoemann et al., 2005).

Single species studies using water collected at variable location during the KEOPS study (Timmermans et al., 2008), showed that growth of the small diatom Chaetoceros brevis was not responsive to the natural iron enrichment observed in the deep water of the Kerguelen plateau (dissolved $[\mathrm{Fe}]=0.35 \mathrm{nmol} \mathrm{L}^{-1}$ ), whereas Fragilariopsis kerguelensis growth was strongly promoted in naturally iron-enriched water. In this case, an average cell number of $29 \pm 6$ per chain was reported (Timmermans et al., 2008), similar to what was observed in this study.

For all the pure phytoplankton cultures studied here (except Fragilariopsis) $\mathrm{Fe}_{\mathrm{ext}}: \mathrm{Fe}_{\text {int }}$ is directly related to the $\mathrm{A} / \mathrm{V}$ (Fig. 4b). $\mathrm{Fe}_{\text {ext }}: \mathrm{Fe}_{\text {int }}$ suggest that single cells with $\mathrm{A} / \mathrm{V} \geq 1.0$ are well adapted to $\mathrm{Fe}$-limited conditions prevailing in the Southern Ocean, which could be explained by a high iron diffusive flux (Pahlow et al., 1997). In this study, diatoms with $\mathrm{A} / \mathrm{V}<0.5$ showed either a fast iron intracellular uptake (Thalassiosira) or high $\mathrm{Fe}_{\mathrm{ext}}: \mathrm{Fe}_{\mathrm{int}}$ (Fragilariopsis), suggesting variable strategies to survive under low iron concentrations. However, more studies are required to verify the robustness of these relationships for other phytoplankton from the Southern Ocean.

\subsection{Importance of organic ligands in controlling $\mathrm{Fe}$ bioavailability to Antarctic phytoplankton}

Based on conventional thermodynamic chemistry and models used to describe biological uptake (e.g. Wilkinson and Buffle, 2004; Shaked et al., 2005), complexation of Fe with ligands should result in a decrease in Fe biological uptake if non- or partially bioavailable complexes are formed. In such case, labile forms of $\mathrm{Fe}$ might contribute to the bioavailable pool of $\mathrm{Fe}$ (van Leeuwen, 1999). Unchanged biouptake should be observed if the Fe complex is fully bioavailable, or if the inorganic $\mathrm{Fe}$ is either enough to sustain the biological requirement or not significantly decreased (Morel et al., 2008). Bioavailability can thus be described as a function of both chemical lability/reactivity (dependant upon possible dissociation within the diffusive layer around the microorganism) and specific and non-specific biological transport pathways (carrier, surface reductase, siderophore receptor/transporter, etc). The presence of organic complexes that can be specifically recognised by micro-organisms (e.g. siderophores), results in an increased apparent bioavailability of $\mathrm{Fe}$ for this specific class of plankton. Each ligand affects $\mathrm{Fe}$ bioaccumulation (a surrogate for its bioavailability) in a similar way for all the strains studied here (except CAT for Chaetoceros sp.). In general, the presence of ligands affects both extracellular and intracellular $\mathrm{Fe}$ in the same way, which is not surprising given the need for Fe to react with the biological surface prior to its transport inside the microorganism.

The least responsive strain to the presence of organic ligands is Thalassiosira antarctica, whereas the most responsive strain is Chaetoceros sp. The fact that Fe bioavailability to Thalassiosira is poorly enhanced by the presence of organic ligands (see below), is likely the result from its ability to rapidly take up $\mathrm{Fe}$, at the limit of its diffusive supply. In this case, labile complexes may contribute to the bioavailable pool of Fe (van Leeuwen, 1999). In this case, to enhance Fe bioaccumulation, the complex needs to be taken up directly or to be specifically bioavailable (e.g. a specific recognition from the cell such as the one for Fe-siderophore complexes).

Both DFB and HBED, are strong ligands for Fe with $\log \mathrm{K}_{\mathrm{Fe}(\mathrm{III}) \mathrm{L}}$ of $41.8 \mathrm{~L} \mathrm{~mol}^{-1}$ for HEBD and $44.1 \mathrm{~L} \mathrm{~mol}^{-1}$ for DFB (NIST, ver. 8.0, stability constant corrected for a ionic strength of zero, using the Davies equation). The $\log$ of the conditional stability constant for Fe(III)DFB (log $\mathrm{K}_{\mathrm{Fe}(\mathrm{III}) \mathrm{DFB}}^{\text {cond }}$ ) previously measured using voltammetric technique varied from 18.5 to $26.5 \mathrm{~L} \mathrm{~mol}^{-1}$ in UV-treated seawater (e.g. Rue and Bruland, 1995; Maldonado et al., 2005). In this study, these strong ligands out-compete ligands naturally present relocating all the Fe into the soluble fraction and decreased Fe bioavailability for all the model strains. Previous studies have demonstrated that siderophores were efficient to solubilise inorganic colloidal forms of iron (Borer et al., 2005). 
By comparing the log of the stability constants observed for $\mathrm{Fe}$ (III)DFB and the interaction of Fe(III) with the biological transporters of a diatom $\left(17.6 \mathrm{~L} \mathrm{~mol}^{-1}\right.$ for T. weissfloggi; Harrison and Morel, 1986; Hudson and Morel, 1990), one can easily realise that DFB could be efficient in decreasing iron bioavailability, except for the species specifically excreting siderophores or associated receptors. Here, as for previous studies (e.g. Maldonado et al., 2005; Hutchins et al., 1999; Hassler and Twiss, 2006), we report that DFB and HBED are efficient in decreasing iron bioavailability to phytoplankton.

Gallocatechin (CAT), is a catecholate siderophore with strong binding affinity for $\mathrm{Fe}\left(\log \mathrm{K}_{\mathrm{Fe} \text { (III)CAT }}^{\text {cond }}=22.6 \mathrm{~L} \mathrm{~mol}^{-1}\right.$ in UV-treated seawater, Maldonado et al., 2005), which partially relocates Fe between the soluble and colloidal phases. Surprisingly, it did not significantly diminish Fe bioavailability for any of the strains studied here. Indeed, an important enhancement of Fe bioavailability was observed for Chaetoceros sp., suggesting that this diatom was able to recognise $\mathrm{Fe}$ bound to this catecholate siderophore. Contrasting response to in-situ ligands, DFB and CAT has already been observed in the subantarctic region by Maldonado et al. (2005). In that study, the presence of $2 \mathrm{nmol} \mathrm{L}^{-1} \mathrm{Fe}$ and $20 \mathrm{nmol} \mathrm{L}^{-1}$ $\mathrm{CAT}$ increased the average $\mathrm{Fe}$ bioaccumulation for all plankton size fractions $(0.2-2,2-20$ and $>20 \mu \mathrm{m})$ as compared with the addition of $2 \mathrm{nmol} \mathrm{L}^{-1} \mathrm{Fe}$ (buffered with EDTA) to ligands naturally present, whereas a decreased Fe bioaccumulation was observed for $2 \mathrm{nmol} \mathrm{L}^{-1} \mathrm{Fe}$ and $20 \mathrm{nmol} \mathrm{L}^{-1}$ DFB addition. In addition, Hutchins et al. (1999) reported a smaller decrease in Fe bioaccumulation to eukaryotic phytoplankton in the presence of catecholate (enterobactin) as compared with hydroxamate (ferrioxamine and ferrichrome) siderophore.

The protoporphyrin IX (PIX) is also a strong ligand for $\mathrm{Fe}\left(\log \mathrm{K}_{\mathrm{Fe}(\mathrm{III}) \mathrm{PIX}}^{\mathrm{cond}}=22.0 \mathrm{~L} \mathrm{~mol}^{-1}\right.$, Rue and Bruland, 1995) resulting in a partial $\mathrm{Fe}$ relocation within the soluble and colloidal phases. The presence of $1 \mathrm{nmol} \mathrm{L}^{-1} \mathrm{Fe}$ and $15 \mathrm{nmol} \mathrm{L}^{-1}$ PIX resulted in an enhanced Fe bioaccumulation as compared to the $1 \mathrm{nmol} \mathrm{L}^{-1} \mathrm{Fe}$ enrichment for the four phytoplankton studied, in accordance with what was previously reported for polar eukaryotic phytoplankton (Hutchins et al., 1999).

Our results suggest that the bioavailability of organic forms of iron is not directly related to iron solubility. Relating iron bioavailability with iron solubility for model phytoplankton (this study) and natural assemblages from the Southern Ocean (Schoemann et al., 2009) suggested that colloidal iron might be a critical fraction to define its bioavailability to phytoplankton. Additional work previously published support this observation. Both inorganic and organic forms of colloidal Fe have been shown to be bioavailable to diatoms (Rich and Morel, 1990; Nodwell and Price, 2001; Chen et al., 2003). In addition, organic colloidal iron are known to be released as a result of the growth and grazing of diatoms (Zhang and Wang, 2004), potentially relieving iron limitation (Barbeau et al., 1996). Finally, organic colloidal forms of iron is present in surface waters (e.g. Hunter and Boyd, 2007), although their chemical nature is still largely unknown.

This study focussed on other type of organic ligands, (poly)saccharides, probably weaker than siderophores or porphyrins, where little information of $\mathrm{Fe}$ complex formation is known. Polysaccharides constitute a significant fraction of storage carbohydrates and exopolymeric substances (EPS; Mancuso et al., 2005; Wang et al., 2006). Storage carbohydrates and EPS are produced by prokaryotes as well as eukaryotic plankton (Hoagland et al., 1993; FreireNordi et al., 2005; Mancuso et al., 2005). For example, diatoms are known to produce EPS involved in substrate attachment, chain formation and nutrient uptake (Hoagland et al., 1993). These substances can be released upon active secretion (e.g. EPS) or cell lysis (e.g. storage products) at concentrations much higher than dissolved Fe (generally 0.1-0.6 $\mathrm{nmol} \mathrm{L}^{-1}$ in the SO, de Baar and de Jong, 2001) or reported siderophores or porphyrins concentrations in natural water (McCormack et al., 2003; Gledhill, 2007; Vong et al., 2007). Dissolved sugar concentrations of $50-4000 \mathrm{nmol} \mathrm{L}^{-1}$ were reported in the SO (Panagiotopoulos and Sempéré, 2005, and references therein). Although polymeric substances found in the ocean are complex, polyfunctional, polydisperse and still remain poorly characterised, uronic acids are often pointed out (here represented by GAL, GLU and ALG). Uronic acids represent a significant fraction of bacterial EPS produced in the Southern Ocean (Mancuso et al., 2005), can be excreted by Antarctic haptophytes (Janse et al., 1996) and are a structural component of the cell wall of some phytoplankton (e.g. Davies et al., 2003). In addition, uronic acids have carboxylic groups known to be reactive with transition metals (e.g. Davies et al., 2003; Fe(III) has a strong affinity for oxygenated ligands, e.g. Morel and Hering, 1983). EPS have been shown to bind transition metals (e.g. Freire-Nordi et al., 2005) and have also been suggested as being important for $\mathrm{Fe}$ in the Southern Ocean (Mancuso et al., 2005). Both coccolithophores and diatoms were shown to excrete organic compounds able to alter $\mathrm{Fe}$ chemical lability and its bioavailability (Boyé and van den Berg, 2000; Rijkenberg et al., 2008). Indeed, the addition of $1.2 \mu \mathrm{mol} \mathrm{L}^{-1}$ hydroxycarboxilic acid (glucaric acid) to iron, further stimulate the phytoplankton from Antarctic winter ice edge (Öztürk et al., 2004). Together with some experiments conducted on natural community in the Southern Ocean (Schoemann et al., 2009), this study, is the first, to our knowledge, to demonstrate that saccharides can stabilise $\mathrm{Fe}$ within the soluble and colloidal phases, as well as quantitatively enhance its bioavailability to selected eukaryotic phytoplankton from the Southern Ocean. It is unlikely that Fe bound to saccharides resulted in species-specific bioavailability, similar to what has been described for siderophores. Since similar enhancement of Fe bioavailability was observed for small uronic acids and larger polysaccharides (dextran), it seems that the enhanced 
bioavailability does not result from direct uptake of the $\mathrm{Fe}$ bound to the saccharides. Finally, since no bacteria were observed in the cultures used in this study (DAPI stain), bacterial degradation cannot account for the enhanced bioavailability observed. In this case, the increased Fe bioavailability in presence of saccharides, could result from a simultaneous Fe stabilisation within the dissolved phase (Chen et al., 2004; Tian et al., 2006, this study), and the formation of chemically labile Fe forms that are rapidly exchangeable with the bioavailable pool (possibly inorganic, Morel et al., 2008). The study from Öztürk et al. (2004) reported an enhanced $\mathrm{Fe}$ (III) photoreduction by primary and possibly secondary photochemical processes in presence of glucaric acid, suggesting that reduction processes and formation of bioavailable and labile $\mathrm{Fe}(\mathrm{II})$ species are critical to increase Fe bioavailability.

Although strong organic ligands for Fe binding in seawater (reported by CLEAdCSV) are reported with stability constants close to what is observed for porphyrins and siderophores (Rue and Bruland, 1995; Croot and Johansson, 2000; Witter et al., 2000; Boyé et al., 2001; Maldonado et al., 2005), their nature is still uncharacterised. The saccharides systematically occur at higher concentrations than that of the dissolved Fe (e.g. Rue and Bruland, 1995; Croot and Johansson, 2000; Boyé et al., 2001), and at levels higher than reported for siderophores and porphyrins (McCormack et al., 2003; Gledhill, 2004, 2007; Vong et al., 2007). If saccharides accounted for part of this Fe organic complexation, or if they were able to significantly outcompete other strong organic ligands reported for $\mathrm{Fe}$, then $\mathrm{Fe}$ bioavailability could be enhanced as a result of the ubiquitous presence of saccharides in natural water.

Global modelling results from Tagliabue et al. (2009) demonstrated the importance of considering the bioavailability of organically complexed Fe. The present study reports that another type of organic ligand can affect Fe bioavailability: the saccharides. These probably represent lower affinity ligand class (denominated as La or L2), that is defined as bioavailable in existing model (Tagliabue and Arrigo, 2006; Tagliabue et al., 2009). To date, the only reported stability constant for a mono-saccharide (gluconic acid) with Fe' in seawater is $10^{9} \mathrm{~L} \mathrm{~mol}^{-1}$ (Croot and Johansson, 2000), situating saccharides within the class of the low affinity ligands (L2). A recent study showed that bacterial exopolymeric substances (mainly poly-saccharides) form weak complexes (fully labile, $\log \mathrm{K}_{\mathrm{Fe}^{\prime} \mathrm{L}}<11 \mathrm{~L} \mathrm{~mol}^{-1}$ ) with $\mathrm{Fe}$ if pre-equilibrated for $24 \mathrm{~h}$ but strong complexes with $\mathrm{Fe}$ if let to equilibrate for 9 weeks (non-labile, log $\mathrm{K}_{\mathrm{Fe}^{\prime} \mathrm{L}}>13 \mathrm{~L} \mathrm{~mol}^{-1}$; Hassler et al., 2009b). In this case, detection of the stability constant was constrained by the analytical window of the CLEAdCSV. Given that saccharides are produced by a wide range of micro-organisms (e.g. Decho, 1990; Hoagland et al., 1993), and are excreted or released upon lysis and grazing, their production and cycling should be considered to improve existing models. Based on current knowledge, we proposed a schematic representation of ligands release and cycling with subsequent effect on iron chemistry and bioavailability to planktonic organisms (Fig. 1, Supplement, see http://www.biogeosciences.net/6/ 2281/2009/bg-6-2281-2009-supplement.pdf).

As mentioned above, the chain-forming Fragilariopsis kerguelensis used in the study would produce EPS (Hoagland et al., 1993) and showed the highest extracellular Fe per surface area for diatoms in unenriched Antarctic seawater. In addition, Phaeocystis, known to produce EPS for their extracellular mucus (Janse et al., 1996), had the highest extracellular Fe per unit of surface area in this study, suggesting that EPS might in fact favour Fe complexation and adsorption to biological surfaces (Schoemann et al., 2001; Hassler et al., 2009b). Preferential binding of EPS has already been demonstrated for other transition metals (e.g. Davies et al., 2003; Freire-Nordi et al., 2005).

Photodissociation of inorganic and organic forms of iron (e.g. Barbeau et al., 2001; Borer et al., 2005; Maldonado et al., 2005) was previously shown to improve its bioavailability. However, not all organic ligands are photolabile, amongst siderophores aquachelin is photolabile (Barbeau et al., 2001) but DFB and CAT are photostable (Maldonado et al., 2005). Alginic acid were found to dissociate when exposed to UV light $(313 \mathrm{~nm}$ ) but not when exposed to visible light (400 nm; Kojima et al., 2001). Mono-saccharides containing carboxylic group were found to be photostable (Kojima et al., 2001). However, under 50\% PAR light and temperature of $1-2^{\circ} \mathrm{C}$, the presence of $\mu$ molar concentrations of a mono-saccharide (Glucaric acid; Oztürk et al., 2004) induced an increased concentration of $\mathrm{Fe}$ (II) but no difference in $\mathrm{H}_{2} \mathrm{O}_{2}$ and organic peroxides concentrations. Under conditions of irradiance and temperature used in this study, based on the mathematical expression from Kuma et al., 1995, the rate of reduction would be negligible. This suggest that photolability of organically bound Fe would not be significant in the present study and thus cannot explain the enhanced $\mathrm{Fe}$ bioavailability measured.

\section{Conclusions}

Given the ubiquitous presence of saccharides in the ocean, these compounds might represent an important factor to control the basal level of soluble and bioavailable Fe. The importance of saccharides on iron bioavailability in the ocean needs thus, to be further investigated, especially with natural plankton communities. In addition, further studies are required to understand the mechanism by which saccharides can promote iron bioavailability to phytoplankton.

Results presented here demonstrate that the use of model phytoplankton is promising to improve mechanistic understanding of $\mathrm{Fe}$ bioavailability (in presence of natural or model organic ligands) and of primary productivity in HNLC regions of the ocean. This study also brings considerations 
about the control that Fe might have on the species distribution observed in the SO.

The differential effect that organic ligands have on the solubility and the bioavailability of Fe, shows that no direct link exist between soluble and bioavailable Fe. In fact, colloidal Fe seems to be an important pool to sustain Fe bioavailability. Bioavailability of organic colloidal Fe to phytoplankton has already been demonstrated in previous studies (e.g. Nodwell and Price, 2001; Chen et al., 2003; Wang and Dei, 2003)

Acknowledgements. C. Hassler was supported by a Commonwealth Scientific and Industrial Research Organization Post-doctoral fellowship and Australian Research Council travel funding. The Belgian Federal Science Policy Office (contract SD/CA/03A) and Belgian French Community (ARC contract no. 2/07-287) gave support to V. Schoemann. This study is also a contribution to the SOLAS international research initiative and the European Network of Excellence EUR-OCEANS (contract no. 511106-2).

The authors wish to thank J. de Jong, J. O'Sullivan and R. Watson, for technical assistance in ICP-MS analysis, K. Karsh for the isolation of the Fragilariopsis kerguelensis, E. C. V. Butler and M. A. Doblin for comments on previous version of this manuscript. We also would like to thank the anonymous referee, D. Hutchins and A. Tagliabue for their comments that contribute in improving this manuscript.

Edited by: K. Hunter

\section{References}

Abraham, E. R., Law, C. S., Boyd, P. W. Lavender, S. J., Maldonado, M. T., and Bowie, A. R.: Importance of stirring in the development of an iron-fertilised phytoplankton bloom, Nature, 407, 727-730, 2000.

Armand, L. K., Cornet-Barthaux, V., Mosseri, J., and Quéguiner, B.: Late summer diatom biomass and community structure on and around the naturally iron-fertilised Kerguelen Plateau in the Southern Ocean, Deep-Sea Res. II, 55, 653-676, 2008.

Barbeau, K., Moffett, J. W., Caron, D. A., Croot, P. L., and Erdner, D. L.: Role of protozoan grazing in relieving iron limitation of phytoplankton, Nature, 380, 61-64, 1996.

Barbeau, K., Rue, E. L., Bruland , K. W., and Butler A.: Photochemical cycling of iron in the surface ocean mediated by microbial iron(III)-binding ligands, Nature, 413, 409-413, 2001.

Becquevort, S., Lancelot, C., and Schoemann, V.: The role of iron in the bacterial degradation of organic matter derived from Phaeocystis Antarctica, Biogeochemistry, 83, 119-135, doi:10.1007/s10533-007-9079-1, 2007.

Borer, P. M., Sulzberger, B., Reichard, P., and Kraemer S. M.: Effect of siderophores on the light-induced dissolution of colloidal iron(III) (hydr)oxides, Mar. Chem, 93, 179-193, 2005.

Boyé, M. and van den Berg, C. M. G.: Iron availability and the release of iron-complexing ligands by Emiliania huxleyi, Mar. Chem., 70, 277-287, 2000.

Boyé, M., van den Berg, C. M. G., de Jong, J. T. M., Leach, H., Croot, P., and de Baar, H. J. W.: Organic complexation of iron in the Southern Ocean, Deep-Sea Res. I, 48, 1477-1497, 2001.
Boyd, P., Watson, A. J., Law, C. S., et al.: A mesoscale phytoplankton bloom in the polar Southern Ocean stimulated by iron fertilization, Nature, 407, 695-702, 2000.

Chen, M., Dei, R. C. H., Wang, W.-X., and Guo, L.: Marine diatom uptake of iron bound with natural colloids of different origins, Mar. Chem., 81, 177-189, 2003.

Chen, M., Wang ,W.-X., and Guo, L.: Phase partitioning and solubility of iron in natural seawater controlled by dissolved organic matter, Global Biogeochem. Cy., 18, GB4013, doi:10.1029/2003GB002160, 2004.

Croot, P. L. and Johansson, M.: Determination of iron speciation by cathodic stripping voltammetry in seawater using the competing ligand 2-(2-thiazolylazo)-p-cresol (TAC), Electroanalysis, 12, 565-576, 2000.

Davis, T. A., Llanes, F., Volesky, B., and Mucci, A.: Metal selectivity of Sargassum spp. and their alginates in relation to their $\alpha$-LGuluronic acid content and conformation, Environ. Sci. Technol., 37, 261-267, 2003.

de Baar, H. J. W., Buma, A. G. J., Nolting, R. F., Cadée, G. C., Jacques, G., and Tréguer, P. J.: On iron limitation of the Southern Ocean: experimental observations in the Weddell and Scotia Seas, Mar. Ecol. Prog. Ser., 65, 105-122, 1990.

de Baar, H. J. W., Van Leeuwe, M. A., Scharek, R., Goeyens, L., Bakker, K. M. J., and Fritsche, P.: Nutrient anomalies in Fragilariopsis kerguelensis blooms, iron deficiency and the nitrate/phosphate ratio (A. C. Redfield) of the Antarctic Ocean, Deep Sea Res. II, 44, 229-260, 1997.

de Baar, H. J. W. and de Jong, J. T. M.: Distribution, sources and sinks of iron in seawater, in: The Biogeochemistry of Iron in Seawater, edited by: Turner, D. R. and Hunter, K. H., IUPAC Series on Analytical and Physical Chemistry of Environmental Systems, vol. 7, Wiley, New York, 123-153, 2001.

de Baar, H. J. W., Boyd, P. W., Coale, K. H., Landry, M. R., Tsuda, A., Assmy, P., Bakker, D. C. E., Bozec, Y., Barber, R. T., Brzezinski, M. A., Buesseler, K. O., Boye, M., Croot, P. L., Gervais, F., Gorbunov, M. Y., Harrison, P. J., Hiscock, W. T., Laan, P., Lancelot, C., Law, C. S., Levasseur, M., Marchetti, A., Millero, F. J., Nishioka, J., Nojiri, Y., van Oijen, T., Riebesell, U., Rijkenberg, M. J. A., Saito, H., Takeda, S., Timmermans, K. R., Veldhuis, M. J. W., Waite, A. M., and Wong, C.-S.: Synthesis of iron fertilization experiments: From the iron age in the age of enlightenment, J. Geophys. Res., 110, C09S16/01-C09S16/24, doi:10.1029/2004JC002601, 2005.

de Jong, J., Schoemann, V., Lannuzel, D., Tison, J.-L., and Mattielli, N.: High-accuracy determination of iron in seawater by isotope dilution multiple collector inductively coupled plasma mass spectrometry (ID-MC-ICP-MS) using nitrilotriacetic acid chelating resin for pre-concentration and matrix separation, Anal. Chim. Acta, 623, 126-139, doi:10.1016/j.aca.2008.06.013, 2008.

Freire-Nordi, C. S., Vieira, A. A. H., Nakaie, C. R., and Nascimento, O. R.: The metal binding capacity of Anabaena spiroides extracellular polysaccharides: an EPR study, Process Biogeochemistry, 40, 2215-2224, 2005.

Gledhill, M., McCormack, P., Ussher, S., Achterberg, E. P., Mantoura, R. F. C., and Worsfold, P. J.: Production of siderophore type chelates by mixed bacterioplankton populations in nutrient enriched seawater incubations, Mar. Chem., 88, 75-83, 2004.

Gledhill, M.: The determination of heme $\mathrm{b}$ in marine phyto- and 
bacterioplankton, Mar. Chem., 103, 393-403, 2007.

Harrison, G. I. and Morel, F. M. M.: Response of the marine diatom Thalassiosira weissflogii to iron stress, Limnol. Oceanogr., 31, 989-997, 1986.

Hassler, C. S. and Twiss, M. R.: Bioavailability of iron sensed by a phytoplanktonic Fe-bioreporter, Environ. Sci. Technol., 40, 2544-2551, 2006.

Hassler, C. S. and Schoemann, V.: Discriminating between intraand extracellular metals using chemical extraction- the case of iron, Limnol. Oceanogr. Methods, 7, 479-489, 2009.

Hassler C., Petrou K., Clementson L., Blackburn S., and Butler E.: Iron limitation for Southern Ocean diatom (Chaetoceros sp.) and haptophyte (Phaeocystis sp.): impact on physiology and iron bioavailability, in preparation, 2009a.

Hassler, C. S., Alasonati, E., Mancuso Nichols C. A., and Slaveykova, V. I.: Exopolysaccharides produced by bacteria isolated from the pelagic Southern Ocean - role in iron binding, chemical reactivity and bioavailability, Mar. Chem., submitted, 2009b.

Hillebrand, H., Dürselen, C. D., Kirschtel, D., Zohary, T., and Pollingher, U.: Biovolume calculation for pelagic and benthic microalgae, J. Phycol., 35, 403-424, 1999.

Hoagland, K. D., Rosowski, J. R., Gretz, M. R., and Roemer, S. C.: Diatom extracellular polymeric substances: function, fine structure, chemistry, and physiology, J. Phycol., 29, 537-566, 1993.

Hudson, R. J. M. and F. M. M. Morel, F. M. M.: Distinguishing between extra- and intracellular iron in marine phytoplankton, Limnol. Oceanogr., 34, 1113-1120, 1989.

Hudson, R. J. M. and Morel, F. M. M.: Iron transport in marine phytoplankton: kinetics of cellular and medium coordination reactions, Limnol. Oceanogr., 35, 1002-1020, 1990.

Hunter K. H. and Boyd, P. W.: Iron-binding ligands and their role in the ocean biogeochemistry of iron, Environ. Chem., 4, 221-232, 2007.

Hutchins, D. A., Witter, A. E., Butler, A., and Luther III, G. W.: Competition among marine phytoplankton for different chelated iron species, Nature, 400, 858-861, 1999.

Janse, I., van Rijssel, M., van Hall, P., Gerwing, G. J., Gottschal, J. C., and Prins, R. A.: The storage glucan of Phaeocystis globosa (prymnesiophyceae) cells, J. Phycol., 32, 382-387, 1996.

Kirchman, D. L., Meon, B., Cottrell, M. T., Hutchins, D. A., Weeks, D., and Bruland, K. W.: Carbon versus iron limitation of bacterial growth in the California upwelling regime, Limnol. Oceanogr., 45, 1681-1688, 2000.

Kojima, M., Takahashi, K., and Nakamura, K.: Cationic dyesensitized degradation of sodium hyaluronate through photon induced electron transfer in the upper excited state. Photochem. Photobiol., 74, 369-377, 2001.

Kuma, K., Nakabayashi, S., and Matsunaga, K.: Photoreduction of $\mathrm{Fe}(\mathrm{III})$ by hydroxycarboxilic acids in seawater, Water Resour., 29, 1559-1569, 1995.

Lam, P. J., Bishop, J. K. B., Henning, C. C., Marcus, M. A., Waychunas, G. A., and Fung, I. Y.: Wintertime phytoplankton bloom in the subarctic Pacific supported by continental margin iron, Global Biogeochem. Cy., 20, GB1006, doi:10.1029/2005GB002557, 2006.

Lannuzel, D., Schoemann, V., de Jong, J., Chou, L., Delille, B., Becquevort, S., and Tison, J. L.: Iron study during a time series in the western Weddell pack ice, Mar. Chem., 108, 85-95, 2008.
Lannuzel D., Remenyi, T., Lam, P., Townsend, A., Ibisanmi, E., Butler, E., Wagener, T., Schoemann, V., and Bowie, A. R.: Distributions of dissolved and particulate iron in the sub-Antarctic and Polar Frontal Southern Ocean (Australian sector), Deep Sea Res. II, accepted, 2009.

Maldonado, M. T. and Price, N. M.: Influence of N substrate on Fe requirements of marine centric diatoms, Mar. Ecol. Prog. Ser., 141, 161-172, 1996.

Maldonado, M. T., Strzepek, R. F., Sander, S., and Boyd, P. W.: Acquisition of iron bound to strong organic complexes, with different Fe binding groups and photochemical reactivities, by plankton communities in Fe-limited subantarctic waters, Global Biogeochem. Cy., 19, GB4S23, doi:10.1029/2005GB002481, 2005.

Mancuso C. A. N., Lardière, S. G., Bowman, J. P., Nichols, P. D., Gibson, J. A. E., and Guézennec, J.: Chemical characterization of exopolysaccharides from Antarctic marine bacteria, Microbiol. Ecol., 49, 578-589, 2005.

McCormack, P., Worsfold, P. J., and Gledhill, M.: Separation and detection of siderophores produced by marine bacterioplankton using high-performance liquid chromatography with electrospray ionization mass spectrometry, Anal. Chem., 75, 26472652, 2003.

McKay, R. L. M., Wilhelm, S. W., Hall, J., Hutchins, D. A., AlRshaidat, M. M. D., Mioni, C. E., Pickmere, S., Porta, D., and Boyd, P. W.: Impact of phytoplankton on the biogeochemical cycling of iron in subantarctic waters southeast of new Zealand during FeCycle, Global Biogeochem. Cy., 19, GB4S24, doi:10.1029/2005GB002482, 2005.

Morel, F. M. M. and Hering, J. G.: Principles and applications of aquatic chemistry, Wiley Interscience, New York, 1993.

Morel, F. M. M., Kustka, A. B., and Shaked, Y.: The role of unchelated $\mathrm{Fe}$ in the iron nutrition of phytoplankton, Limnol. Oceanogr., 53, 400-404, 2008.

Nodwell, L. M. and Price, N. M.: Direct use of inorganic colloidal iron by marine mixotrophic phytoplankton, Limnol. Oceanogr., 46, 765-777, 2001.

Öztürk, M., Croot, P. L., Bertilsson, S., Abrahamsson, K., Karlson, B., David, R., Fransson, A., and Sakshaug, E.: Iron enrichment and photoreduction of iron under UV and PAR in the presence of hydroxycarboxylic acid: implications for phytoplankton growth in the Southern Ocean, Deep-Sea Res. II, 51, 2841-2856, 2004.

Pahlow, M., Riebesell, U., and Wolf-Gladrow, D. A.: Impact of cell shape and chain formation on nutrient acquisition by marine diatoms, Limnol. Oceanogr., 42, 1660-1672, 1997.

Panagiotopoulos, C. and Sempéré, R.: Analytical methods for the determination of sugars in marine samples: A historical perspective and future directions, Limnol. Oceanogr. Methods, 3, 419454, 2005.

Panagiotopoulos, C., Repeta, D. J., and Johnson, C. G.: Characterization of methyl sugars, 3-deoxysugars and methyl deoxysugars in marine high molecular weight dissolved organic matter, Org. Geochem., 38, 884-896, 2007.

Poorvin, L., Rinta-Kanto, J. M., Hutchins, D. A., and Wilhelm, S. W.: Viral release of iron and its bioavailability to marine plankton, Limnol. Oceanogr., 49, 1734-1741, 2004.

Porter, K. G. and Feig, Y. S.: The use of DAPI for identifying and counting aquatic microflora, Limnol. Oceanogr., 25, 943-948, 1980.

Price, N. M. and Morel, F. M. M.: Biological cycling of iron in the 
ocean, Met. Ions Biol. Syst., 35, 1-36, 1998.

Rich, H. W. and Morel, F. M. M.: Availability of well-defined iron colloids to the marine diatom Thalassiosira weissflogii, Limnol. Oceanogr., 35, 652-662, 1990.

Rijkenberg, M. J. A., Gerringa, L. J. A., Timmermans, K. R., Fischer, A. C., Kroon, K. J., Buma, A. G. J., Wolterbeek, B. T., and de Baar, H. J. W.: Enhancement of the reactive iron pool by marine diatoms, Mar. Chem., 109, 29-44, 2008.

Rue, E. L. and Bruland, K. W.: Complexation of iron(III) by natural organic ligands in the Central North Pacific as determined by a new competitive ligand equilibration/adsorptive cathodic stripping voltammetric method, Mar. Chem., 50, 117-138, 1995.

Santschi, P. H., Hung, C.-C., Schultz, G., Alvarado-Quiroz, N., Guo, L., Pinckney, J., and Walsh, I.: Control of acid polysaccharide production and ${ }^{234} \mathrm{Th}$ and POC export fluxes by marine organisms, Geophys. Res. Lett., 30, 1044, doi:10.1029/2002GL016046, 2003.

Sarthou, G., Timmermans, K. R., Blain, S., and Treguer, P.: Growth physiology and fate of diatoms in the ocean: a review, J. Sea Res., 53, 25-42, 2005.

Schoemann, V., Wollast, R., Chou, L., and Lancelot, C.: Effects of photosynthesis on the accumulation of $\mathrm{Mn}$ and Fe by Phaeocystis colonies, Limnol. Oceanogr., 46, 1065-1076, 2001.

Schoemann, V., Becquevort, S., Stefels, J., Rousseau, V., and Lancelot, C.: Phaeocystis blooms in the global ocean and their controlling mechanisms: a review, J. Sea Res., 53, 43-66, 2005.

Schoemann, V., Hassler, C., Masson, F., Dumont, I., Lannuzel, D., Bowie, A., and Becquevort, S.: The effect of organic ligands on Fe bioavailability to natural plankton communities of the Southern Ocean, in preparation, 2009.

Schmidt, M. A. and Hutchins, D. A.: Size-fractionated biological iron and carbon uptake along a coastal to offshore transect in the NE Pacific, Deep-Sea Res. II, 46, 2487-2503, 1999.

Shaked, Y., Kustka, A. B., and Morel, F. M. M.: A general kinetic model for iron acquisition by eukaryotic phytoplankton, Limnol. Oceanogr., 50, 872-882, 2005.

Strzepek, R. F. and Harrison P. J.: Photosynthetic architecture differs in coastal and oceanic diatoms, Nature, 431, 689-692, 2004.

Strzepek, R. F., Maldonado, M. T., Higgins, J. L., Hall, J., Safi, K., Wilhelm, S. W., and Boyd, P. W.: Spinning the "Ferrous Wheel": The importance of the microbial community in an iron budget during the FeCycle experiment, Global Biogeochem. Cy., 19, GB4S26, doi:10.1029/2005GB002490, 2005.

Sunda, W. G. and Huntsman, S. A.: Iron uptake and growth limitation in oceanic and coastal phytoplankton, Mar. Chem., 50, 189-206, 1995

Sunda, W. G. and Huntsman, S. A.: Interrelated influence of iron, light and cell size on marine phytoplankton growth, Nature, 390, 389-392, 1997.

Tagliabue, A. and K. R.: Arrigo. Processes governing the supply of iron to phytoplankton in stratified seas, J. Geophys. Res., 111, C06019, doi:10.1029/2005JC003363, 2006.

Tagliabue, A., Bopp, L., Aumont, O., and Arrigo, K. R.: The influence of light and temperature on the marine iron cycle: From theoretical to global modelling, Global Biogeochem. Cy., 23, GB2017, doi:10.1029/2008GB003214, 2009.

Takeda, S.: Influence of iron availability on nutrient consumption ratio of diatoms in oceanic waters, Nature, 393, 774-777, 1998.

Tang, D. and Morel, F. M. M.: Distinguishing between cellular and Fe-oxide-associated trace elements in phytoplankton, Mar. Chem., 98, 18-30, 2006.

Tian, F., Frew, R. D., Sander, S., Hunter, K. A., and Ellwood, M. J.: Organic iron(III) speciation in surface transects across a frontal zone: the Chatham Rise, New Zealand, Mar. Freshwater Res. 57, 533-544, 2006.

Timmermans, K. R., Davey, M. S., van der Wagt, B., Snoek, J., Geider, R. J., Veldhuis, M. J. W., Gerringa, L. J. A., and de Baar, H. J. W.: Co-limitation by iron and light of Chaetoceros brevis, $C$. dichaeta and C. calcitrans (Bacillariophyceae), Mar. Ecol. Prog. Ser., 217, 287-297, 2001.

Timmermans, K. R., van der Wagt, B., and de Baar, H. J. W.: Growth rates, half-saturation constants, and silicate, nitrate, and phosphate depletion in relation to iron availability of four large, open-ocean diatoms from the Southern Ocean, Limnol. Oceanogr., 49, 2141-2151, 2004.

Timmermans, K. R., Veldhuis, M. J. W., Laan, P., and Brussaard, C. P. D.: Probing natural iron fertilization near the Kerguelen (Southern Ocean) using natural phytoplankton assemblages and diatom cultures, Deep-Sea Res. II, 55, 693-705, 2008.

Tovar-Sanchez, A., Sanudo-Wilhelmy, S. A., Garcia-Vargas, M., Weaver, R. S., Popels, L. C., and Hutchins, D. A.: A trace metal clean reagent to remove surface-bound iron from marine phytoplankton, Mar. Chem, 82, 91-99, 2003.

Trick, C. G., Andersen, R. J., Price, N. M., and Harrison, P. J.: Examination of hydroxamate-siderophore production by neritic eukaryotic marine phytoplankton, Mar. Biol., 75, 9-17, 1983.

Twining, B. S., Baines, S. B., Fisher, N. S., and Landry, M. R.: Cellular iron contents of plankton during the Southern Ocean Iron Experiment (SOFeX), Deep-Sea Res. I, 51, 1827-1850, 2004.

van Leeuwen, H. P.: Metal speciation dynamics and bioavailability: inert and labile complexes, Environ. Sci. Technol., 33, 3743 3748, 1999.

van Oijen, T., Veldhuis, M. J. W., Gorbunov, M. Y., Nishioka, J., van Leeuwe, M. A., and de Baar, H. J. W.: Enhanced carbohydrate production by Southern Ocean phytoplankton in response to in situ iron fertilization, Mar. Chem., 93, 33-52, 2005.

Völker, C. and Wolf-Gladrow, D. A.: Physical limits on iron uptake mediated by siderophores or surface reductases, Mar. Chem., 65, 227-244, 1999.

Vong, L., Laës, A. and Blain, S.: Determination of iron-porphyrinlike complexes at nanomolar levels in seawater, Anal. Chim. Acta, 588, 237-244, 2007.

Wang, W. X. and Dei, R. C. H.: Bioavailability of iron complexed with organic colloids to the cyanobacteria Synechococcus and Trichodesmium, Aquat. Microb. Ecol., 33, 247-259, 2003.

Wang, D., Henrichs, S. M., and Guo, L.: Distributions of nutrients, dissolved organic carbon and carbohydrates in the western Arctic Ocean, Cont. Shelf Res., 26, 1654-1667, 2006.

Wilkinson, K. J. and Buffle, J.: Critical evaluation of physicochemical parameters and processes for modeling the biological uptake of trace metals in environmental (aquatic) systems, in: Physicochemical kinetics and transport at biointerfaces, edited by: van Leeuwen, H. P. and Köster, W., John Wiley \& Sons, New-York, 445-533, 2004.

Witter, A. E., Hutchins, D. A., Butler, A., and Luther III, G. W.: Determination of conditional stability constants and kinetic constants for strong model Fe-binding ligands in seawater, Mar. Chem., 69, 1-17, 2000. 
Worms, I., Simon, D. F., Hassler, C. S., and Wilkinson, K. J.: Bioavailability of trace metals to aquatic microorganisms: importance of chemical, biological and physical processes on biouptake, Biochimie, 88, 1721-1731, 2006.
Zhang, W. and Wang, W.-X.: Colloidal organic carbon and trace metal $(\mathrm{Cd}, \mathrm{Fe}$, and $\mathrm{Zn}$ ) releases by diatom exudation and copepod grazing, J. Exp. Mar. Biol. Ecol., 307, 17-34, 2004. 